UDC 577.128.15:615.015.4

review

ISSN 1330-9862

(FTB-1418)

\title{
Biocatalytic Synthesis of Chiral Pharmaceutical Intermediates
}

\author{
Ramesh N. Patel \\ Process R \& D, Bristol-Myers Squibb, New Brunswick, NJ 08903, USA \\ Received: July 29, 2004 \\ Revised version: September 10, 2004 \\ Accepted: November 22, 2004
}

\begin{abstract}
Summary
The production of single enantiomers of drug intermediates has become increasingly important in the pharmaceutical industry. Chiral intermediates and fine chemicals are in high demand from both the pharmaceutical and agrochemical industries for the preparation of bulk drug substances and agricultural products. The enormous potential of microorganisms and enzymes for the transformation of synthetic chemicals with high chemo-, regio- and enantioselectivities has been demonstrated. In this article, biocatalytic processes are described for the synthesis of chiral pharmaceutical intermediates.
\end{abstract}

Key words: biocatalysis, chiral intermediates, antiviral, anticancer, antihypertensive, anti-infective, receptor agonists/antagonists, enantioselective enzymatic de-protection

\section{Introduction}

The production of single enantiomers of chiral intermediates has become increasingly important in the pharmaceutical industry (1). Single enantiomers can be produced by chemical or chemo-enzymatic synthesis. The advantage of biocatalysis over chemical synthesis is that enzyme-catalyzed reactions are often highly enantioselective and regioselective. They can be carried out at ambient temperature and atmospheric pressure, thus avoiding the use of more extreme conditions that can cause problems with isomerization, racemization, epimerization and rearrangement. Microbial cells and enzymes derived from them can be immobilized and reused for many cycles, and enzymes can be over-expressed to make biocatalytic processes economically efficient. A number of review articles (2-8) on the use of enzymes in organic synthesis have been published. The current review provides examples of the use of enzymes for the synthesis of single enantiomers of key intermediates used in the preparation of pharmaceuticals.

\section{Antiviral Agents}

\section{Atazanavir}

An essential step in the life cycle of human immunodeficiency virus (HIV-1) is the proteolytic processing of its precursor proteins. This processing is accomplished by HIV-1 protease, a virally encoded enzyme. Inhibition of HIV-1 protease arrests the replication of HIV in vitro. Thus, HIV-1 protease is an attractive target for chemotherapeutic intervention $(9,10)$. Atazanavir 1 [Scheme 1A] is an acyclic aza-peptidomimetic that is a potent HIV protease inhibitor $(11,12)$. The original process was utilized for small-scale preparation of Atazanavir to support initial development (13) and subsequently an improved process for the large-scale synthesis of Atazanavir was developed (14).

An alternative biocatalytic process was developed for the preparation of a key chiral intermediate required for the synthesis of Atazanavir (15). The diastereoselective microbial reduction of (1S)-[3-chloro-2-oxo-1-(phenylme-

*Corresponding author; E-mail: ramesh.patel@bms.com 
[A]<smiles>COC(=O)NC(C(=O)NC(=O)NN(Cc1ccc(-c2ccccn2)cc1)[C@H](O)Cc1cccc(C(C)(C)C)c1)C(C)(C)C</smiles>

$[\mathrm{B}]$
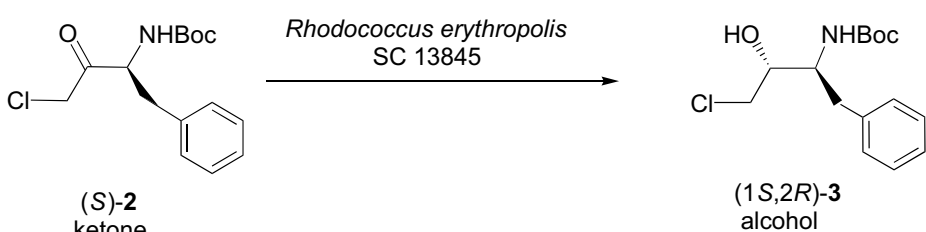

[C]
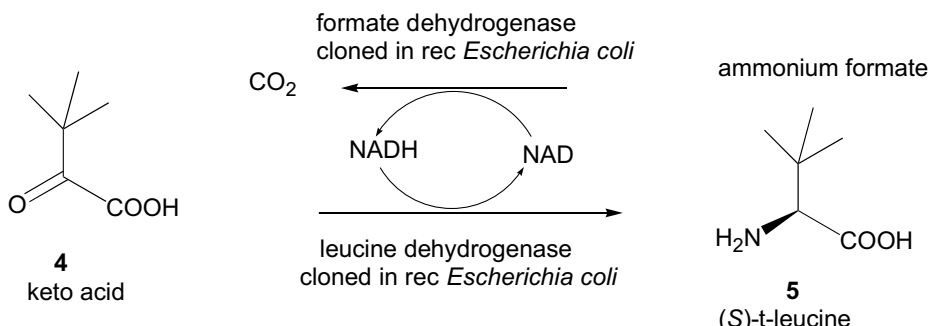

Scheme 1. Synthesis of chiral intermediates for antiviral agent 1: (A) Enantioselective enzymatic reduction of (1S)[3-chloro-2-oxo-1(phenylmethyl)propyl]carbamic acid 1,1-dimethyl-ethyl ester 2 to the corresponding $(1 S, 2 R) 3$ by Rhodococcus erythropolis SC 13845. (B) Synthesis of chiral intermediates for antiviral agent 1: enzymatic reductive amination of keto acid 4 to $(S)$-t-leucine 5 by leucine dehydrogenase

Boc - t-butylcarbonyl group

thyl)propyl]carbamic acid, 1,1-dimethyl-ethyl ester (S)-2 to homochiral chlorohydrin (1S,2R)-[3-chloro-2-oxo-1-(phenylmethyl)propyl]carbamic acid, 1,1-dimethyl-ethyl ester $(1 S, 2 R)-3$, has been demonstrated [Scheme 1B]. Among microbial cultures evaluated, Rhodococcus, Brevibacterium and Hansenula strains reduced (S)-2 to (1S,2R)-3. Three strains of Rhodococcus gave $>90 \%$ yield with a diastereomeric purity of $>98 \%$ and enantiomeric excess (e.e.) of $99.4 \%$. Rhodococcus erythropolis SC 13845 and Rhodococcus sp. 16002 were grown in a 25-L fermentor for $48 \mathrm{~h}$. The cells were collected and suspended in 70 $\mathrm{mM}$ potassium phosphate buffer $(\mathrm{pH}=7.0)$, and the resulting cell-suspensions were used to carry out the two-stage process for biotransformation of (S)-2. A reaction yield of $>92 \%$, diastereomeric purities of $>98 \%$ and enantiomeric excesses of $99.3-99.4 \%$ for alcohol $(1 S, 2 R)-3$ were obtained. An efficient single-stage fermentation-biotransformation process was developed for the reduction of ketone (S)-2 with cells of Rhodococcus erythropolis SC 13845. A reaction yield of $95 \%$, diastereomeric purity of $98.2 \%$ and enantiomeric excess of $99.4 \%$ for $(1 S, 2 R)-3$ were obtained.

Synthesis of Atazanavir also required the (S)-tertiary leucine 5 [Scheme 1C]. An enzymatic process was developed for the synthesis 5 . Enzymatic reductive amination of keto acid 4 to amino acid 5 by leucine dehydrogenase from Thermoactinimyces intermedius has been demonstrated. Leucine dehydrogenase from T. interme- dius was cloned and over-expressed in Escherichia coli. The reaction required ammonia and NADH as a cofactor. NAD produced during the reaction was regenerated back to NADH using formate dehydrogenase from $\mathrm{Pi}$ chia pastoris. Formate dehydrogenase from P. pastoris was also cloned and over-expressed in Escherichia coli. A reaction yield of $>95 \%$ and enantiomeric excess of $>99.5$ $\%$ were obtained for 5 at $100 \mathrm{~g} / \mathrm{L}$ of substrate input (R. Hanson, S. Goldberg, R. Patel, unpublished results).

\section{BMS-186318}

Barrish et al. (16) reported the discovery of a new class of selective HIV protease inhibitors that incorporate a C-2 symmetric aminodiol core as a key structural feature. Members of this class, particularly compound 6 [Scheme 2], display potent anti-HIV activity in cell culture. The diastereoselective microbial reduction of (1S)-[3-chloro-2-oxo-1-(phenylmethyl)-propyl]carbamic acid, 1,1-dimethyl-ethyl ester (S)-2 to (1S,2S)-[3-chloro-2-hydroxy-1-(phenylmethyl)propyl]carbamic acid, 1,1-dimethyl-ethyl ester $(1 S, 2 S)-7$, a key intermediate in the total chemical synthesis of BMS-186318, has been demonstrated (17). Among 100 microorganisms screened for the reduction, the two best cultures, Streptomyces nodosus SC 13149 and Mortierella ramanniana SC 13850, were used to convert $(S)-2$ to $(1 S, 2 S)-7$ in $60-65 \%$ reaction yields, $99.9 \%$ e.e.'s and $>99 \%$ diastereomeric purities. An efficient single-stage fermentation-biotransformation 


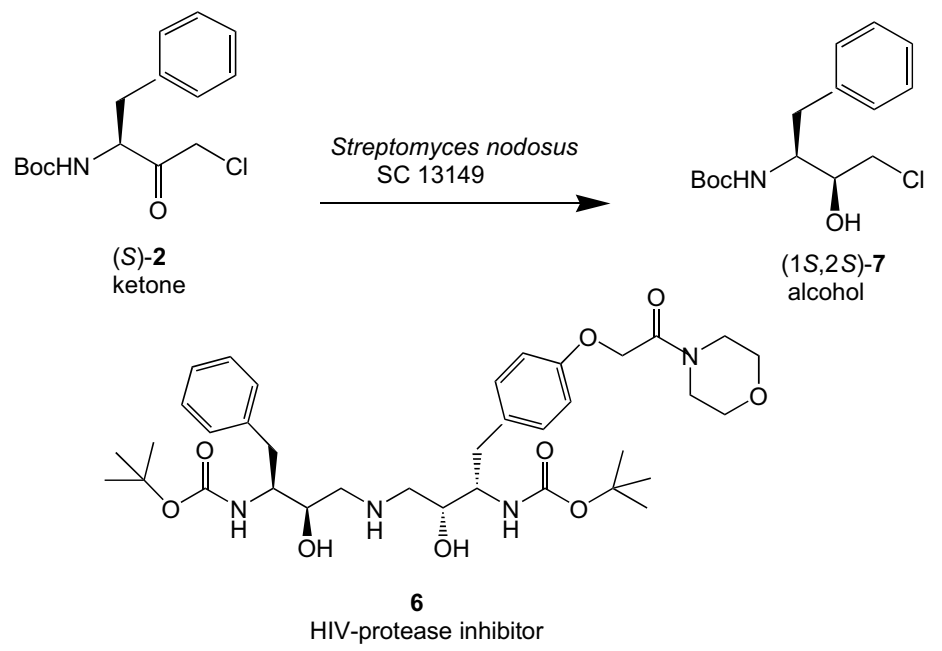

Scheme 2. Synthesis of chiral intermediates for HIV-protease inhibitor 6: enantioselective enzymatic reduction of (1S)-[3-chloro-2-oxo-1(phenylmethyl)propyl]carbamic acid, 1,1-dimethyl-ethyl ester 2 to the corresponding $(1 S, 2 S) 7$ by Streptomyces nodosus SC 13149

Boc - t-butylcarbonyl group

process was developed using cells of $S$. nodosus SC 13149. A reaction yield of $80 \%$, a diastereomeric purity of $>99 \%$ and an e.e. of $99.8 \%$ were obtained for $(1 S$, $2 \mathrm{~S})-7$ at $10 \mathrm{~g} / \mathrm{L}$ of substrate input.

\section{Indinavir}

Cis-(1S,2R)-indandiol 9 or trans-(1R,2R)-indandiol 9 [Scheme $3 \mathrm{~A}$ ] are both potential precursors to cis- $(1 S$, 2R)-1-aminoindan-2-ol 12, a key chiral synthon for Cri- xivan (Indinavir) 13 [Scheme 3B], an HIV protease inhibitor. Enrichment and isolation of microbial cultures yielded two strains, Rhodococcus sp. B 264-1 (MB 5655) and I-24 (MA 7205), capable of biotransforming indene 8 to cis-( $1 S, 2 R)$-indandiol and trans- $(1 R, 2 R)$-indandiol respectively (18). Isolate MB 5655 was found to have a toluene dioxygenase, while isolate MA 7205 was found to harbor both toluene and naphthalene dioxygenases as well as a naphthalene monooxygenase that catalyzes the

$[\mathrm{A}]$

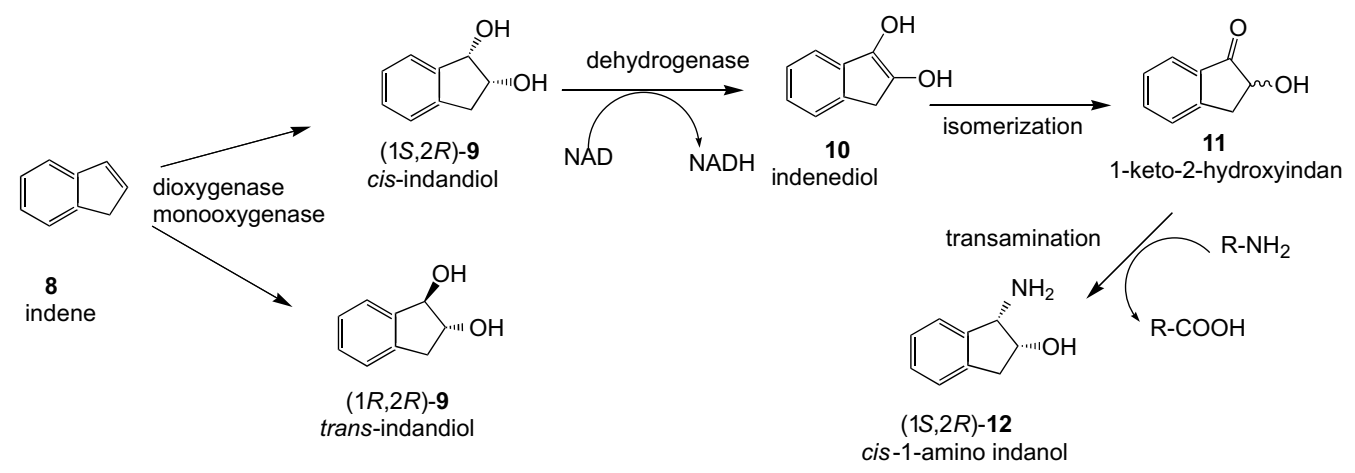

[B]

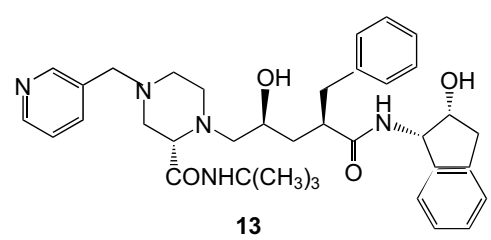

Indinavir (Crixivan)

[C]
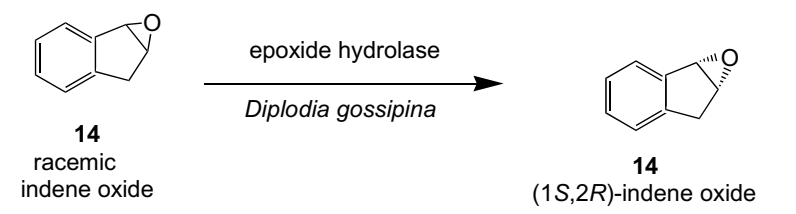

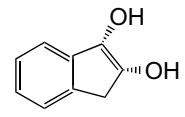

15

$(R)$-indanediol

Scheme 3. Synthesis of chiral intermediates for Crixivan 13: (A) Microbial oxygenation of indene 8 to cis-indandiol 9 and trans-indandiol 9. (C) Resolution of racemic indene oxide $\mathbf{1 4}$ to $(1 S, 2 R)$-indene oxide $\mathbf{1 4}$ by epoxide hydrolase from Diplodia gossipina 
above biotransformation. When scaled up in a 14 -L fermentor, MB5655 produced up to $2.0 \mathrm{~g} / \mathrm{L}$ of cis-(1S,2R)-indandiol 9 with e.e. $>99 \%$. Rhodococcus sp. MA 7205 cultivated under similar conditions produced up to 1.4 $\mathrm{g} / \mathrm{L}$ of trans- $(1 R, 2 R)$-indandiol 9 with e.e. $>98 \%$. Process development studies yielded titers of greater than 4.0 $\mathrm{g} / \mathrm{L}$ of trans-(1R,2R)-indandiol 9 (19). A metabolic engineering approach (20) and a directed evolution technique (21) were evaluated to avoid side reactions, block degradative pathways and enhance the key reaction to convert indene to cis-amino indanol or cis-indandiol.

Multi-parameter flow cytometry was employed for the measurement of indene toxicity to the strain. Concentrations of indene up to $0.25 \mathrm{~g} / \mathrm{L}(0.037 \mathrm{~g}$ (indene) $/ \mathrm{g}$ (dry cell)) in batch bioconversions did not influence cell physiology. Using this information, a single-phase indene fed-batch bioconversion was carried out. Cytoplasmic membrane integrity and membrane polarization of a large number of cells were measured during bioconversions and compared to a control in order to assess any toxic effects of indene feeding. Indene supply at a rate of $0.1 \mathrm{~g} \mathrm{~L}^{-1} \mathrm{~h}^{-1}$ was feasible without any deleterious effects. Cis- $(1 S, 2 R)$-indandiol 9 production rates were enhanced from 20 up to $200 \mathrm{mg} \mathrm{L}^{-1} \mathrm{~h}^{-1}$, in a silicone oil two-liquid-phase system, by a combination of suitable indene feeding rates in the stationary phase and operating with a high biomass concentration (22).

In an alternate process, an epoxide hydrolase from Diplodia gossipina was used for the resolution of racemic indene oxide 14 [Scheme 3C]. The desired enantiomer $(1 S, 2 R)$-indene oxide 14 , a chiral intermediate for Crixivan, was obtained in $14 \%$ yield and $>99.9 \%$ e.e.

\section{Lobucavir}

Lobucavir 20 [Scheme 4] is a cyclobutyl guanine nucleoside analog that is potentially useful as an antiviral agent for the treatment of herpes virus and hepatitis $B$ (23). The lobucavir pro-drug L-valine $[1 S, 2 R, 3 R)-3-(2-$ -amino-1,6-dihydro-6-oxo-9H-purin-9-yl)-2-(hydroxymethyl)cyclobutyl]methyl ester monohydrochloride 22, in which one of the two hydroxyls is coupled to valine, has also been considered for development. Regioselective aminoacylation was difficult to achieve by chemical procedures but appeared to be suitable for an enzymatic approach (24). Synthesis of the lobucavir pro-drug 22 required regioselective coupling of one of the two hydroxyl groups of lobucavir with valine. Enzymatic processes were developed for the aminoacylation of either hydroxyl group of lobucavir (24). The selective hydrolysis of $\mathrm{N}, \mathrm{N}^{\prime}$-bis[(phenylmethoxy)carbonyl]bis[L-valine], $\mathrm{O}, \mathrm{O}^{\prime}$-[(1S,2R,3R)-3-(2-amino-6-oxo-1H-purin-9-yl)cyclobutan-1,2-diyl]methyl ester 16 [Scheme 4] was accomplished with lipase M (Amano Enzyme Company) to yield 18 in $83 \%$ yield. When bis[valine],O, $\mathrm{O}^{\prime}-[(1 S, 2 R$, $3 R$ )-3-(2-amino-6-oxo-1H-purin-9-yl)cyclobutan-1,2-diyl] methyl ester 17 dihydrochloride was hydrolysed with lipase from Candida cylindraceae, 19 was obtained in $87 \%$ yield. Compound 21, the final intermediate for the lobucavir pro-drug 22, could be obtained by transesterification of lobucavir using ChiroCLEC ${ }^{\mathrm{TM}}$ BL from Altus Company (61\% yield) or more selectively by using the lipase from Pseudomonas cepacia immobilized on Accurell polypropylene (84\% yield).
[A]

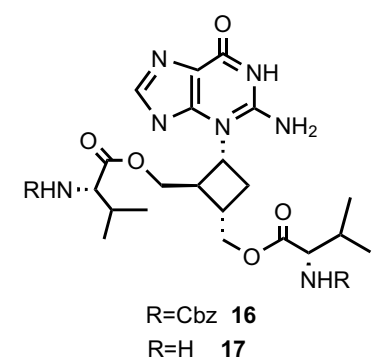

[B]

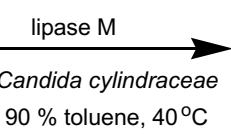

Chiro CLEC ${ }^{\text {TM }}$ BL Pseudomonas cepacia lipase PS-30 (IME)
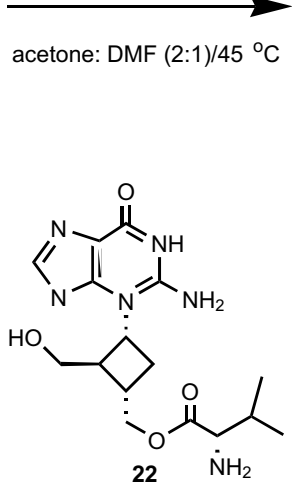

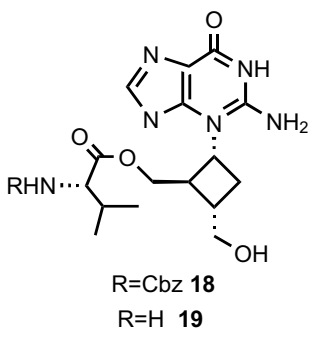<smiles>[R]C(C)C(N)C(=O)OCC1CC2C(CO)CC2N1c1ncnc2c(=O)[nH]cnc12</smiles>

21

desired product $\mathrm{R}=\mathrm{Cbz}$ or Boc

Scheme 4. Synthesis of chiral intermediates for the lobucavir pro-drug 22: (A) Regioselective enzymatic hydrolysis of 16 and 17. (B) Regioselective enzymatic aminoacylation of lobucavir 20 $\mathrm{Cbz}$ - carbobenzyloxy group 


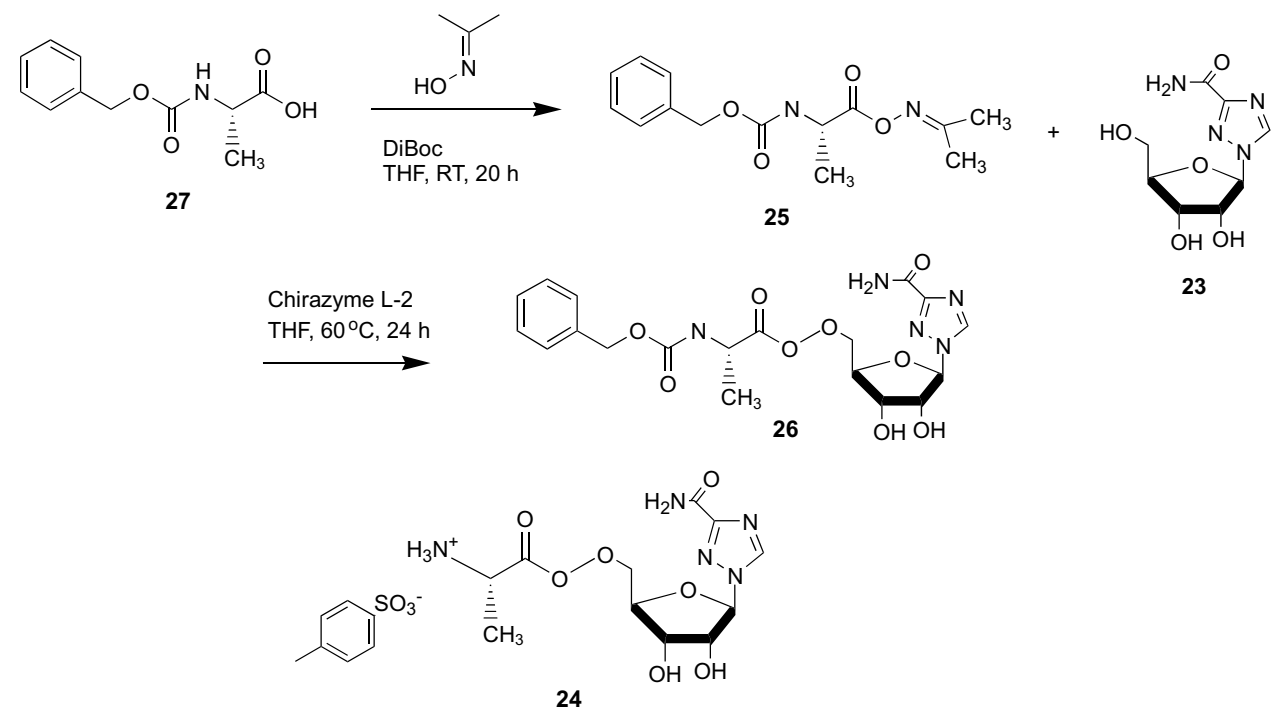

Scheme 5. Synthesis of chiral intermediates ribavirin pro-drug 24: regioselective enzymatic acylation of ribavirin 23 with oxome ester of L-carbobenzyloxy(cbz)-alanine 25 to give desired product 26 using Novozym 435

\section{Ribavirin pro-drug}

Ribavirin 23 [Scheme 5] is an antiviral agent used in combination with $\alpha-2 \beta$ interferon to treat hepatitis $C$ (25-27). Although this therapy is effective against hepatitis $C$ virus, it has several side effects $(28,29)$. To improve the pharmacokinetics profile and reduce side effects, ribavirin pro-drug was considered for development. In a series of preclinical evaluations, the alanine ester of ribavirin 24 [Scheme 5] showed improved bioavalibility and reduced side effects. The synthesis of 24 required the acylation of unprotected ribavirin. Chemical acylation gave a mixture of mono-, di- and triacylated products. An enzymatic process was developed for the regioselective acylation of ribavirin 23 with oxome ester of L-carbobenzyloxy(cbz)-alanine 25 to give the desired $\mathbf{2 6}$ using Novozym 435 (Candida antarctica lipase B). The chemical de-protection of $\mathbf{2 6}$ gave $\mathbf{2 4}$. In a preparative-scale process, the coupling of 27 with acetone oxime in the presence of di-t-butyl dicarbonate in THF was carried out giving 25 in greater than $96 \%$ yield. At the end of the reaction, the reaction mixture was diluted three-fold with THF and ribavirin was added and the acylation was initiated by the addition of lipase. Following 24-h reaction at $60{ }^{\circ} \mathrm{C}$, the product 26 was isolated in 85 $\%$ yield (30).

\section{Anti-Infective Drugs}

\section{Microbial hydroxylation of pleuromutilin or mutilin}

Pleuromutilin 28 [Scheme 6] is an antibiotic from Pleurotus or Clitopilus basidiomycete strains that kills mainly gram-positive bacteria and mycoplasms. A more active semi-synthetic analogue, tiamulin, has been developed for the treatment of infections of animals and poultry and has been shown to bind to prokaryotic ribosomes and inhibit protein synthesis (31). Metabolism of pleuromutilin derivatives results in hydroxylation by microsomal cytochrome P-450 at the 2- or 8-position and inactivates the antibiotics (32). Modification of the 8-po- sition of pleuromutilin and analogues is of interest as a mean of preventing the metabolic hydroxylation. Microbial hydroxylation of pleuromutilin $\mathbf{2 8}$ or mutilin $\mathbf{3 0}$ would provide a functional group at this position to allow further modification at this site to avoid metabolic hydroxylation. The target analogues would maintain the biological activity of the parent compounds but would not be susceptible to metabolic inactivation.

Biotransformation of mutilin and pleuromutilin by microbial cultures has been investigated to provide a source of 8-hydroxymutilin or 8-hydroxypleuromutilin (33). Streptomyces griseus strains SC 1754 and SC 13971 (ATCC 13273) hydroxylated mutilin to (2S)-hydroxymutilin 31, (8S)-hydroxymutilin 32 and (7S)-hydroxymutilin 33 [Scheme 6]. Cunninghamella echinulata SC 16162 (NRRL $3655)$ gave (2S)-hydroxymutilin 31 or (2R)-hydroxypleuromutilin 29 from biotransformation of mutilin or pleuromutilin, respectively. The biotransformation of mutilin by the $S$. griseus strain SC 1754 was scaled up in 15-, 60-, and 100-L fermentations to produce a total of $49 \mathrm{~g}$ of (8S)-hydroxymutilin (BMS-303786), $17 \mathrm{~g}$ of (7S)-hydroxymutilin (BMS-303789) and $13 \mathrm{~g}$ of (2S)-hydroxymutilin (BMS-303782) from $162 \mathrm{~g}$ of mutilin (33).

A C-8 ketopleuromutilin 34 derivative has been synthesized from the biotransformation product 8-(S)-hydroxymutilin (34). A key step in the process was the selective oxidation at C-8 of 8 -hydroxymutilin using tetrapropylammonium perruthenate. The presence of the C-8 keto group gave an interesting intramolecular chemistry to afford a compound with a novel pleuromutilin-derived 35 ring system, which was achieved by acid-catalyzed conversion of C-8 ketopleuromutilin.

\section{Anticancer Agents}

\section{Paclitaxel}

Among the antimitotic agents, paclitaxel 36 [Scheme 7], a complex, polycyclic diterpene, exhibits a unique mode of action on microtubule proteins responsible for 


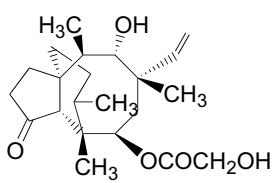

28

pleuromutilin

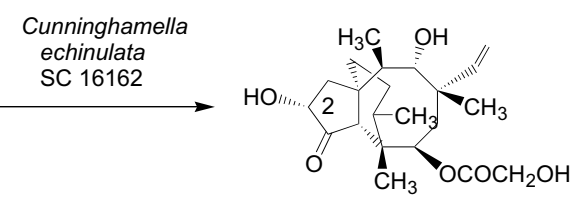

2-(R)-hydroxypleuromutilin

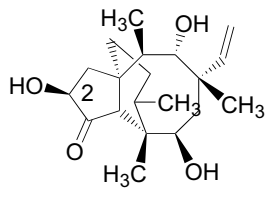

2-(S)-hydroxymutilin

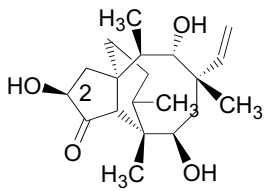

31

2-(S)-hydroxymutilin

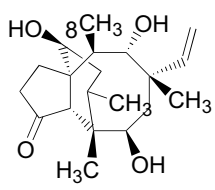

32

8-(S)-hydroxymutilin

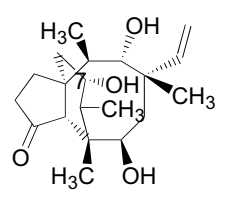

33

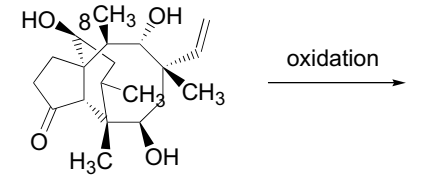

32

8-(S)-hydroxymutilin

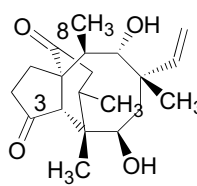

34

C-8 ketopleuromutilin (diketone)

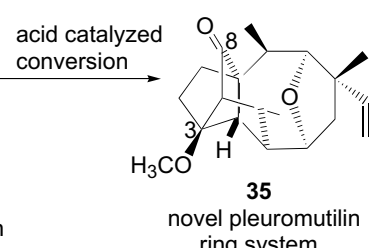

ring system

Scheme 6. Microbial hydroxylation of pleuromutilin 28 and mutilin 30

the formation of the spindle during cell division (35-39). Paclitaxel inhibits the depolymerization process of microtubulin $(39,40)$. Various types of cancers have been treated with paclitaxel and the results in treatment of ovarian cancer and metastatic breast cancer are very promising. Paclitaxel was originally isolated from the bark of the yew, Taxus brevifolia, and has also been found in other Taxus species in relatively low yield. Paclitaxel was obtained from T. brevifolia bark in $0.07 \%$ yield and it required cumbersome purification from the other related taxanes. It is estimated that about $9000 \mathrm{~kg}$ of yew bark (the equivalent of about 3000 trees) are needed to produce $1 \mathrm{~kg}$ of purified paclitaxel $(41,42)$. The development of a semi-synthetic process for the production of paclitaxel from baccatin III 37 (paclitaxel without the C-13 side-chain) or 10-deacetyl-baccatin III 38 (10-DAB, paclitaxel without the C-13 side-chain and the C-10 acetate) and C-13 paclitaxel side-chain 40 or 44 [Scheme 7] is a very promising approach. Baccatin III and 10-DAB can be derived from renewable resources

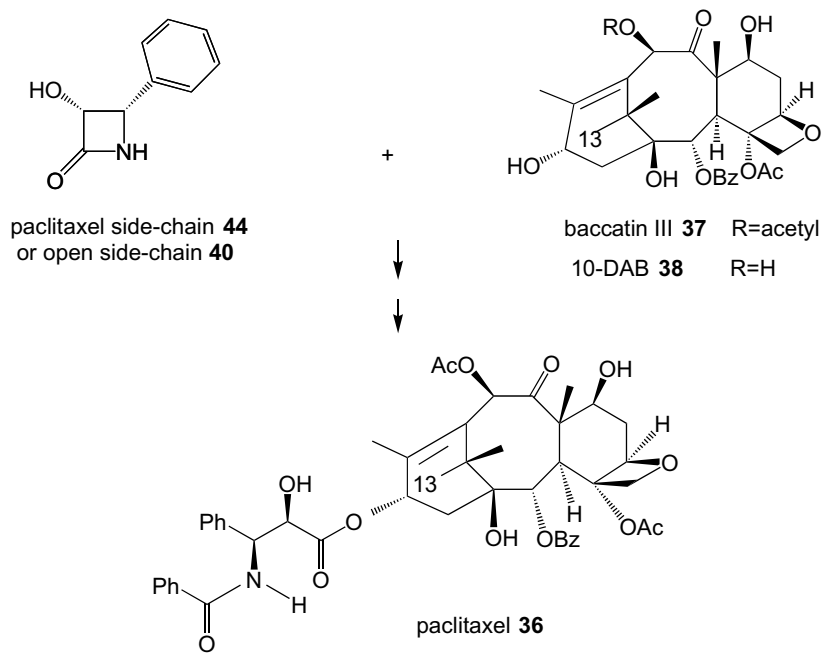

Scheme 7. Semisynthesis of paclitaxel 36, an anticancer agent. Coupling of baccatin III 37 and C-13 paclitaxel side-chain synthons 40 or 44 
such as extracts of needles, shoots and young Taxus cultivars (43). Thus the preparation of paclitaxel by semi-synthetic process eliminates cutting down the large yew trees.

By using selective enrichment techniques, two strains of Nocardioides were isolated from soil samples that contained novel enzymes C-13 taxolase, C-10 deacetylase and C-7 xylosidase (44-46). The extracellular C-13 taxolase derived from the filtrate of the fermentation broth of Nocardioides albus SC 13911 [Scheme 8A] catalyzed the cleavage of $\mathrm{C}-13$ side-chain from paclitaxel and related taxanes such as taxol $C$, cephalomannine, 7- $\beta$-xylosyltaxol, 7- $\beta$-xylosyl-10-deacetyltaxol, and 10-deacetyltaxol [Scheme 8A]. The intracellular C-10 deacetylase derived from the fermentation of Nocardioides luteus SC 13912 [Scheme 8B] catalyzed the cleavage of C-10 acetate from paclitaxel, related taxanes and baccatin III to yield $10-\mathrm{DAB}$. The C-7 xylosidase derived from the fermentation of Moraxella sp. [Scheme 8C] catalyzed the cleavage of C-7 xylosyl group from various taxanes. Fermentation processes were developed for growth of $N$. albus SC 13911, N. luteus SC 13912 and Moraxella sp. to produce C-13 taxolase, C-10 deacetylase and C-7 xylosidase, respectively, in 5000-L batches, and a bioconversion process was demonstrated for the conversion of paclitaxel and related taxanes in extracts of Taxus cultivars to a single compound 10-DAB using both enzymes. In the bioconversion process, ethanolic extracts of the whole young plant of five different cultivars of Taxus were first treated with a crude preparation of the C-13 taxolase to give complete conversion of measured taxanes to baccatin III and 10-DAB in 6 hours. Whole cells of Nocardioides luteus SC 13192 were then added to the reaction mixture to give complete conversion of baccatin III to 10-DAB. The concentration of 10-DAB was increased by 6- to 24-fold in the extracts treated with enzymes. The bioconversion process was also applied to extracts of the bark of $T$. bravifolia to give a 12 -fold increase in 10-DAB concentration. The enhancement of 10-DAB concentration in yew extracts was potentially useful in increasing the amount of this key precursor for the paclitaxel semi-synthetic process using renewable resources.

Another key step in the paclitaxel semi-synthetic process is the preparation of chiral C-13 paclitaxel side-chain. Two different enantioselective enzymatic processes were developed for the preparation of chiral C-13 paclitaxel side-chain synthon $(47,48)$. In one process, the enantioselective microbial reduction of 2-keto-3-(N-benzoylamino)-3-phenyl propionic acid ethyl ester 39 to yield (2R,3S)-(-)-N-benzoyl-3-phenyl isoserine ethyl ester 40 [Scheme 9A] was demonstrated (47). Hansenula polymorpha SC 13865 and Hansenula fabianii SC 13894 catalyzed the enantioselective reduction of ketone 39 to the $(2 R, 3 S)$-ethyl ester 40 in greater than $80 \%$ reaction yield and greater than $94 \%$ e.e. in a preparative-scale bioreduction using cell suspensions in independent experiments. A $20 \%$ yield of undesired anti-diastereomers content was obtained with H. polymorpha SC 13865 com-

$[\mathrm{A}]$

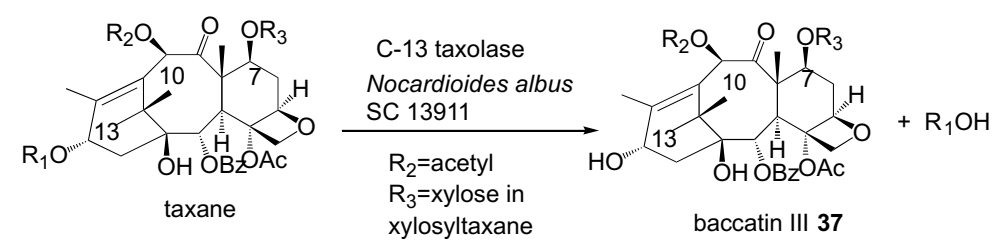

$[\mathrm{B}]$

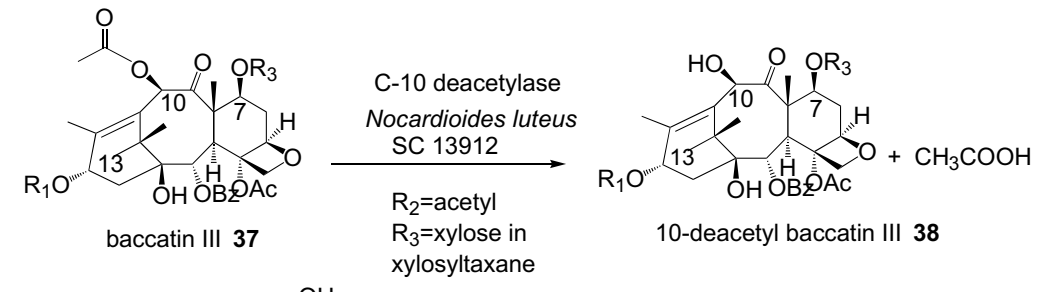

[C]
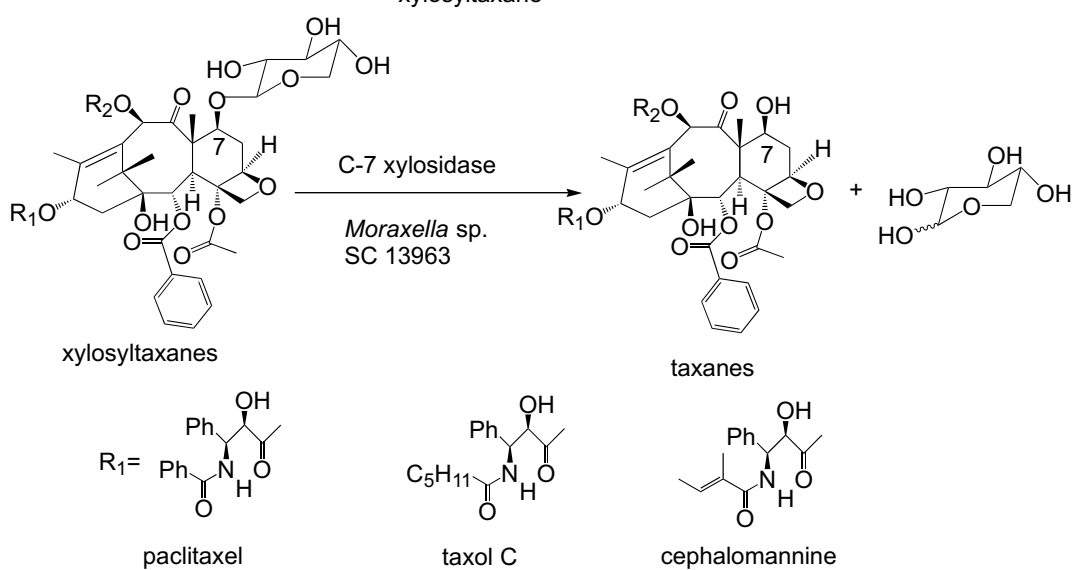

Scheme 8. (A) Enzymatic hydrolysis of C-13 side-chain of taxanes by C-13 taxolase from Nocardioides albus SC 13911. (B) Enzymatic hydrolysis of C-10 acetate of taxanes and baccatin III 37 by C-10 deacetylase from Nocardioides luteus SC 13912. (C) Enzymatic hydrolysis of C-7 xylose by C-7 xylosidase from Moraxella sp. 13963 
[A]

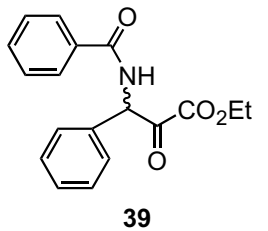

39

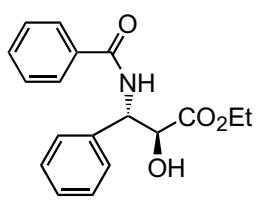

$(2 S, 3 R) 40$

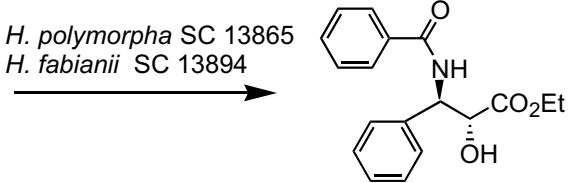

$(2 R, 3 S) 40$

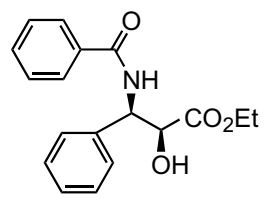

$(2 S, 3 S) \mathbf{4 0}$

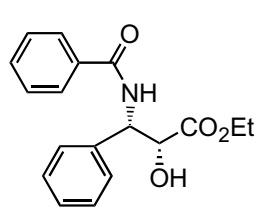

$(2 R, 3 R) \mathbf{4 0}$

$[\mathrm{B}]$<smiles>CC(=O)OC1C(=O)NC1c1ccccc1</smiles>

41

racemic acetate

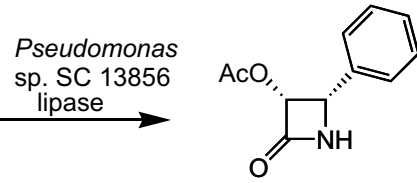

43

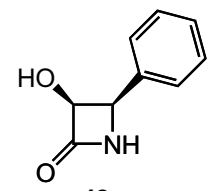

42

(3S)-alcohol<smiles>CC(=O)O[C@H]1C(=O)N[C@@H]1c1ccccc1</smiles>

(3R)-acetate

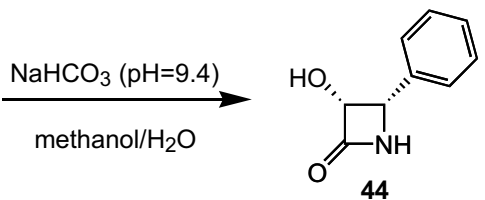

(3R)-alcohol

[C-13 taxol side-chain]

Scheme 9. Enzymatic synthesis of C-13 side-chain of paclitaxel 36: (A) Enantioselective microbial reduction of 2-keto-3-(N-benzoylamino)-3-phenyl propionic acid, ethyl ester 39. (B) Enantioselective enzymatic hydrolysis of cis-3-(acetyloxy)-4-phenyl-2-azetidinone 41

pared with a $10 \%$ yield with $H$. fabianii SC 13894 . A $99 \%$ e.e. was obtained with $H$. polymorpha SC 13865 compared with a $94 \%$ e.e. with $H$. fabianii SC 13894 . In a single-stage fermentation/bioreduction process (15-L scale), cells of $H$. fabianii were grown in a 15 -L fermentor for $48 \mathrm{~h}$; the bioreduction process was then initiated by addition of $30 \mathrm{~g}$ of substrate and $250 \mathrm{~g}$ of glucose and continued for $72 \mathrm{~h}$. A reaction yield of $88 \%$ and an e.e. of $95 \%$ were obtained for $(2 R, 3 S)$-ethyl ester 40 .

In an alternate enzymatic resolution process for the preparation of $\mathrm{C}-13$ paclitaxel side-chain, the enantioselective enzymatic hydrolysis of racemic acetate cis-3-(acetyloxy)-4-phenyl-2-azetidinone 41 [Scheme 9B] to the corresponding $(S)$-alcohol 42 and the unreacted desired $(R)$-acetate 43 was demonstrated (43) by lipase PS-30 from Pseudomonas cepacia (Amano International Enzyme Company) and BMS lipase (extracellular lipase derived from the fermentation of Pseudomonas sp. SC 13856). Reaction yields of greater than $48 \%$ (theoretical maximum yield $50 \%$ ) and e.e. of greater than $99.5 \%$ were obtained for $R$-acetate. BMS lipase and lipase PS-30 were immobilized on Accurel polypropylene (PP) and immobilized lipases were reused (10 cycles) without the loss of enzyme activity, productivity or the e.e. of the product 43 in the resolution process. The enzymatic process was scaled up to $250-\mathrm{L}$ ( $2.5 \mathrm{~kg}$ of substrate input) using immobilized BMS lipase and lipase PS-30, re- spectively. From each reaction batch, $(R)$-acetate 43 was isolated in mol fraction, $x=45 \%$ yield (theoretical maximum yield $50 \%$ ) and $99.5 \%$ e.e. (R)-acetate was chemically converted to $(R)$-alcohol 44 . The C-13 paclitaxel side-chain synthon (40 or 44 ), produced either by the reductive or resolution process, could be coupled to bacattin III 37 after protection and de-protection to prepare paclitaxel by semi-synthetic process (49).

\section{Oral taxane}

Due to poor solubility of paclitaxel, various groups are developing water-soluble taxane analogs (50). Taxane 45 [Scheme $10 \mathrm{~A}$ ] is an anticancer water-soluble taxane derivative given orally, which was as effective as intravenous paclitaxel in five tumor models [murine M109 lung and $\mathrm{C} 3 \mathrm{H}$ mammary $16 / \mathrm{C}$ cancer, human A2780 ovarian cancer cells (grown in mice and rats) and HCT/pk colon cancer]. Compound 45 was also active in a human, hormone-dependent, prostate tumor model, CWR-22 , and just as effective as antiandrogen chemotherapy (50).

The enantioselective enzymatic hydrolysis of cis-3-(acetyloxy)-4-(1,1-dimethylethyl)-2-azetidinone 46 [Scheme 10B] to the corresponding undesired (S)-alcohol 47 and unreacted desired $(R)$-acetate 48 was carried out using immobilized lipase PS-30 or BMS lipase. Reaction yields of greater than $48 \%$ and e.e. of greater than $99 \%$ 
[A]

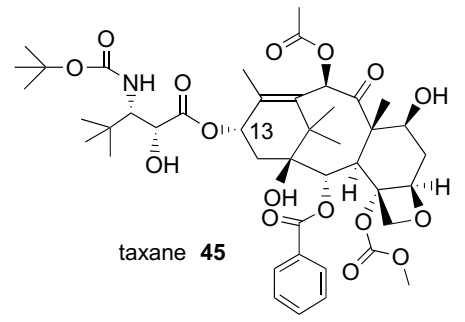

$[\mathrm{B}]$

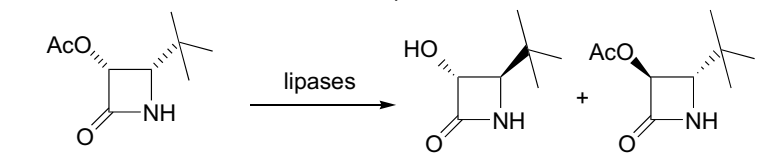

racemic acetate 46

(S)-alcohol 47

$(R)$-acetate 48

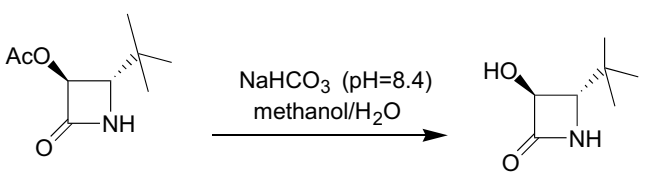

$[\mathrm{C}]$

$(R)$-acetate 48

$(R)$-alcohol 49

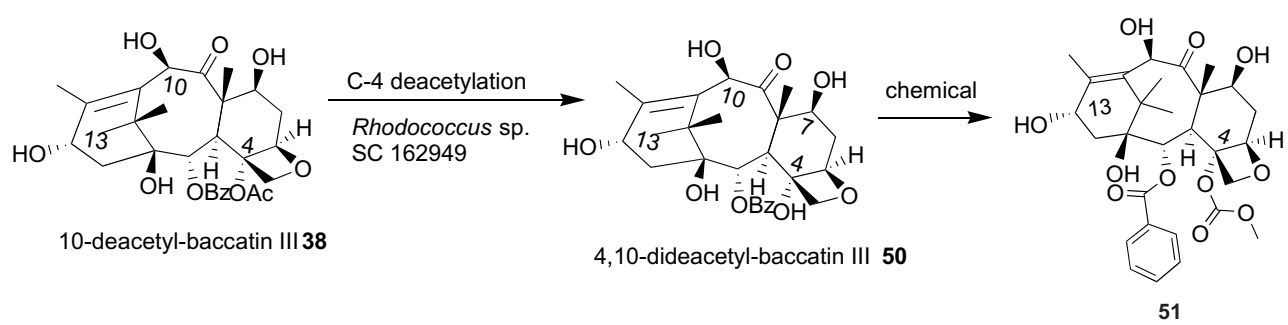

Scheme 10. (A) Enzymatic synthesis of C-13 side-chain 49 of orally active taxane 45. (B) Enantioselective enzymatic hydrolysis of cis-3-acetyloxy-4-(1,1-dimethylethyl)-2-azetidinone 46. (C) Enzymatic C-4 deacetylation of 10-deacetyl-baccatin III 38

were obtained for desired 48. Acetoxy $\beta$-lactam 48 was converted to hydroxy $\beta$-lactam 49 for semisynthesis of oral taxane 45. Immobilized lipase was reused over many cycles in this process (51).

The synthesis of oral taxane 45 also required 4,10-dideacetyl baccatin $\mathbf{5 0}$ [Scheme 10C] as starting material for the synthesis of C-4 methylcarbonate derivative of 10-deacetyl-baccatin III 51. A microbial process was developed for deacetylation of 10-deacetyl-baccatin III 38 to 4,10-dideacetyl-baccatin III 50 using a Rhodococcus sp. SC 162949 isolated from soil using an enrichment culture technique (52).

\section{Retinoid Receptor Gamma Specific Agonists}

A number of studies have demonstrated that retinoids (vitamin A derivatives) are essential for normal growth, vision, tissue homeostasis, and reproduction $(53,54)$. Retinoic acid and its natural and synthetic analogs (retinoids) exert a wide variety of biological effects by binding to or activating a specific receptor or sets of receptors (55). They affect cellular growth and differentiation and are promising drugs for the treatment of cancers (56). A few retinoids are already in clinical use for the treatment of dermatological diseases such as acne and psoriasis (57). (R)-3-fluoro-4-[hydroxy-(5,6,7,8-tetrahydro-5,5,8,8-tetramethyl-2-naphthalenyl)-acetyl]aminobenzoic acid 52 [Scheme 11] is a retinoic acid receptor gamma-specific agonist potentially useful as a dermatological and anticancer drug (58).
The chiral intermediate ethyl-2-(R)-hydroxy-2- $\left(1^{\prime}, 2^{\prime}, 3^{\prime}\right.$, $4^{\prime}$-tetrahydro-1', $1^{\prime}, 4^{\prime}, 4^{\prime}$-tetramethyl-6'-naphthalenyl)acetate 53 and the corresponding acid $\mathbf{5 4}$ were prepared as intermediates in the synthesis of the retinoic acid receptor gamma-specific agonist 52 (59). Enantioselective microbial reduction of ethyl-2-oxo-2-(1', $2^{\prime}, 3^{\prime}, 4^{\prime}$-tetrahydro- $1^{\prime}, 1^{\prime}, 4^{\prime}, 4^{\prime}$ -tetramethyl-6-naphthalenyl) acetate 55 to alcohol 53 was carried out using Aureobasidium pullulans SC 13849 in 98 $\%$ yield and with an e.e. of $96 \%$ (59). Among microorganisms screened for the reduction of 2-oxo-2-( $\left(1^{\prime}, 2^{\prime}, 3^{\prime}, 4^{\prime}-\right.$ -tetrahydro- $1^{\prime}, 1^{\prime}, 4^{\prime}, 4^{\prime}$-tetramethyl-6'-naphthalenyl)acetic acid 56 to hydroxy acid 54, Candida maltosa SC 16112 and two strains of Candida utilis (SC 13983, SC 13984) gave greater than $53 \%$ reaction yields with greater than $96 \%$ e.e. At the end of the reaction, hydroxyester $\mathbf{5 3}$ was adsorbed onto XAD-16 resin and, after filtration, recovered in $94 \%$ yield from the resin with acetonitrile extraction. The recovered $(R)$-hydroxyester 53 was treated with Chirazyme L-2 or pig liver esterase to convert it to the corresponding ( $R$ )-hydroxyacid 54 in quantitative yield. The enantioselective microbial reduction of keto amide 57 to the corresponding (R)-hydroxyamide 58 by $A$. pullulans SC 13849 was also demonstrated (59).

\section{Anti-Alzheimer's Drugs}

Resolution of racemic secondary alcohols

(S)-2-Pentanol 59 and (S)-heptanol 61 [Scheme 12A] are intermediates in the synthesis of several potential anti-Alzheimer's drugs that inhibit synthesis and release 
$[\mathrm{A}]$<smiles>CCOC(=O)C(=O)c1ccc2c(c1)C(C)(C)CCC2(C)C</smiles>

[B]<smiles>CCCCCC1(C)c2ccc(C(O)C(=O)O)cc2C(C)(C)CCC1(C)C</smiles>

$[C]$

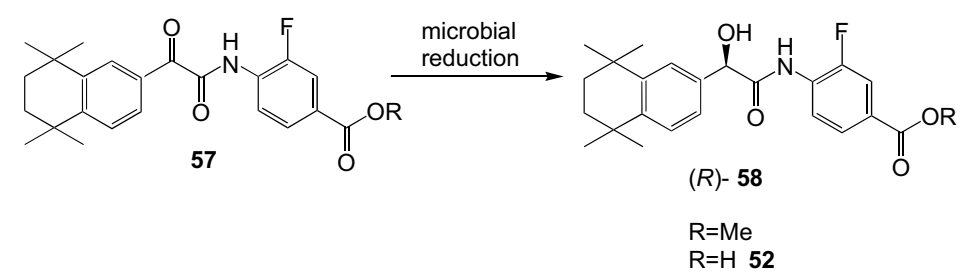

Scheme 11. Enzymatic synthesis of chiral synthons for the retinoid receptor gamma specific Agonist 52: (A) Enantioselective microbial reduction of ethyl 2-oxo-2-(1', $2^{\prime}, 3^{\prime}, 4^{\prime}$-tetrahydro- $1^{\prime}, 1^{\prime}, 4^{\prime}, 4^{\prime}$-tetramethyl-6'-naphthalenyl) acetate 55 to $(R)$-hydroxy ester 53. (B) Enantioselective microbial reduction of 2-oxo-2-(1', $2^{\prime}, 3^{\prime}, 4^{\prime}$-tetrahydro- $1^{\prime}, 1^{\prime}, 4^{\prime}, 4^{\prime}$-tetramethyl-6'-naphthalenyl) acetate 56 to $(R)$-hydroxy acid 54. (C) Enantioselective microbial reduction of keto amide 57 to $(R)$ hydroxy amide 58

[A]

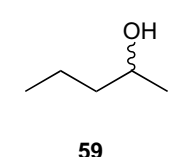

racemic 2-pentanol

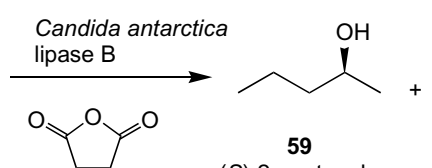

(S)-2-pentanol

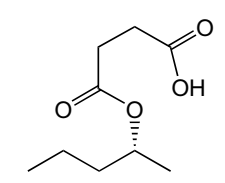

60

$(R)$-2-pentyl hemisuccinate

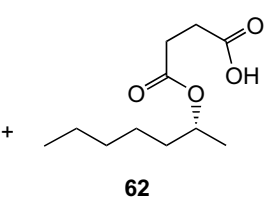

(S)-2-heptanol

(R)-2-heptyl hemisuccinate

$[B]$

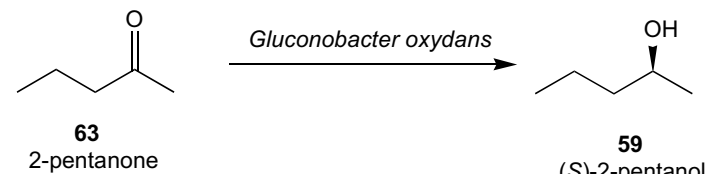

(S)-2-pentanol

Scheme 12. (A) Synthesis of chiral intermediates for anti-Alzheimer's drugs: enzymatic resolution of racemic 2-pentanol 59 and 2-heptanol 61 by Candida antarctica lipase. (B) Enantioselective microbial reduction of 2-pentanone 63 to (S)-2-pentanol

of $\beta$-amyloid peptide $(60,61)$. The enzymatic resolution of racemic 2-pentanol and 2-heptanol by lipase B from Candida antarctica has been demonstrated (62). Commercially available lipases were screened for the enantioselective acetylation of racemic 2-pentanol in hexane in the presence of vinyl acetate as an acyl donor.

C. antarctica lipase B efficiently catalyzed this reaction, giving yields of $49 \%$ (theoretical maximum yield $50 \%$ ) and $99 \%$ e.e. for (S)-2-pentanol. In a preparative-scale acetylation (100 $\mathrm{g}$ of input), $44.5 \mathrm{~g}$ of (S)-2-pentanol was isolated with an e.e. of $98 \%$. Among the acylating agents tested, succinic anhydride was best due to easy recovery of the (S)-2-pentanol at the end of the reaction.
Using 0.68 mol-equivalent of succinic anhydride [Scheme 12A] and $13 \mathrm{~g}$ of lipase B per $\mathrm{kg}$ of racemic 2-pentanol, which was present as both substrate and solvent, a reaction yield of mol fraction $x=43 \%$ and an e.e. of greater than $98 \%$ were obtained for (S)-2-pentanol. The resolution of 2-heptanol was also carried out using lipase B under similar conditions to give a reaction yield of mol fraction $x=44 \%$ and an e.e. of greater than $99 \%$ of (S)-2-heptanol, isolated in $40 \%$ overall yield.

In an alternative approach, the enantioselective reduction of 2-pentanone 63 to the corresponding (S)-2-pentanol [Scheme 12B] was demonstrated for Gluconobacter oxydans. Using Triton X-100 treated cells of G. 
oxydans, preparative scale reduction of 2-pentanone was carried out and $1.06 \mathrm{~kg}$ of (S)-2-pentanol was prepared (63).

\section{Enzymatic Reduction of 5-Oxohexanoate and 5-Oxohexane nitrile}

Ethyl-(S)-5-hydroxyhexanoate 65 and (S)-5-hydroxyhexane nitrile 67 [Scheme 13A] are key chiral intermediates in the synthesis of several pharmaceuticals. Both chiral compounds have been prepared by enantioselective reduction of ethyl-5-oxohexanoate 64 and 5-oxohexane nitrile 66 by Pichia methanolica SC 16116. Reaction yields of $80-90 \%$ and e.e.'s greater than $95 \%$ were obtained for each chiral compound. In an alternate approach, the enzymatic resolution of racemic 5-hydroxyhexane nitrile 67 [Scheme 13B] by enzymatic succinylation was demonstrated using immobilized lipase PS-30 to obtain (S)-5-hydroxyhexane nitrile 67 in $35 \%$ yield (maximum yield is $50 \%$ ). (S)-5 Acetoxyhexane nitrile 68 was prepared by enantioselective enzymatic hydrolysis of racemic 5-acetoxyhexane nitrile by Candida cylindracea lipase. A reaction yield of $42 \%$ and an e.e. of greater than $99 \%$ were obtained (64).

\section{Enantioselective Microbial Reduction of Substituted Acetophenone}

The chiral intermediate ethyl-(S)-1-(2'-bromo-4'-fluorophenyl)ethanol 70 [Scheme $14 \mathrm{~A}$ ] was prepared by the enantioselective microbial reduction of 2-bromo-4-fluoro acetophenone 69 (65). Organisms from the gen-
$[\mathrm{A}]$<smiles>CCOC(=O)CCCC(C)=O</smiles>

64

ethyl-5-oxohexanoate<smiles>CC(=O)CCCC#N</smiles>

5-oxohexane nitrile

[B]<smiles>C[C@@H](O)CCCC#N</smiles>

$$
67
$$

5-hydroxyhexane nitrile

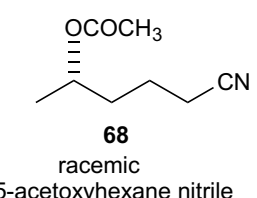

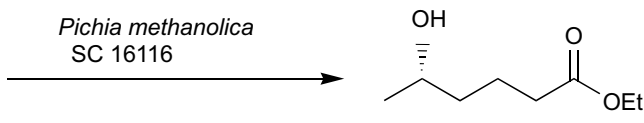

65

ethyl-5-(S)-hydroxyhexanoate
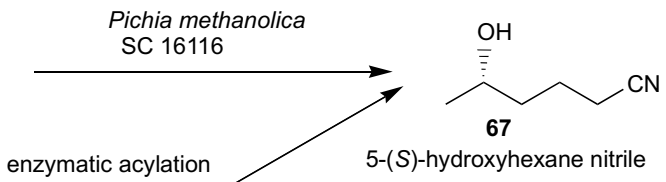

5-(S)-hydroxyhexane nitrile

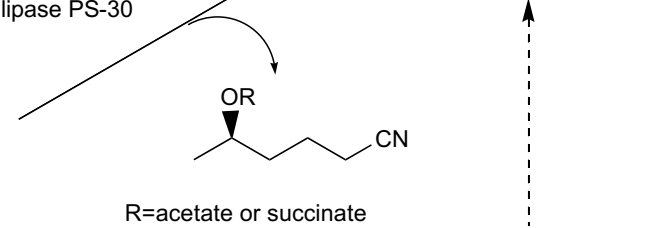

$\uparrow$

$\mathrm{R}=$ acetate or succinate

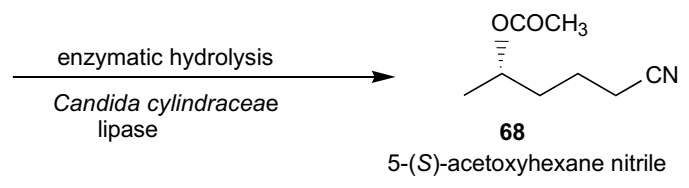

Scheme 13. (A) Synthesis of chiral intermediates for anti-Alzheimer's drugs: enantioselective microbial reduction of ethyl-5-oxohexanoate 64 and 5-oxohexane nitrile 66. (B) Enzymatic resolution of 5-hydroxyhexane nitrile 67 and 5-acetoxyhexane nitrile 68

[A]<smiles>CC(=O)c1ccc(F)cc1Br</smiles>
microorganisms

ketone 69

[B]<smiles>[R]C(=O)CCCc1cc(F)ccc1C(C)=O</smiles>
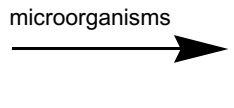<smiles>C[C@@H](O)c1ccc(F)cc1Br</smiles>

(S)-alcohol 70<smiles>[R]C(=O)CCCc1cc(F)ccc1[C@H](C)O</smiles>

$\begin{array}{cc}R=\text { methyl } & 72 \\ \text { ethyl } & 74\end{array}$

t-butyl 76

Scheme 14. Synthesis of chiral intermediates for anti-Alzheimer's drugs: (A) Enantioselective microbial reduction of 2-bromo-4-fluoro acetophenone 69. (B) Enantioselective microbial reduction of methyl-4-(2'-acetyl-5'-fluorophenyl) butanoate 71 
era Candida, Hansenula, Pichia, Rhodotorula, Saccharomyces and Sphingomonas and baker's yeast reduced 69 to 70 in greater than $90 \%$ yield and $99 \%$ e.e. In an alternative approach, the enantioselective microbial reduction of methyl-, ethyl- and t-butyl-4-(2'-acetyl-5'-fluorophenyl) butanoates 71, 73, and 75 [Scheme 13B], respectively, was demonstrated using strains of Candida and Pichia. Reaction yields of $40-53 \%$ and e.e.'s of $90-99 \%$ were obtained for the corresponding (S)-hydroxy esters 72, 74, and 76. The reductase that catalyzed the enantioselective reduction of keto esters was purified to homogeneity from cell extracts of Pichia methanolica SC 13825. It was cloned and expressed in Escherichia coli and recombinant cultures were used for the enantioselective reduction of the keto-methyl ester $\mathbf{7 1}$ to the corresponding (S)-hydroxy methyl ester 72 . On preparative scale, a reaction yield of $98 \%$ and an e.e. of $99 \%$ were obtained (65).

\section{Melatonin Receptor Agonist}

Enantioselective enzymatic hydrolysis of 1-[2',3'-dihydro benzo(b)furan-4'-yl]-1,2-oxirane

Epoxide hydrolase catalyzes the enantioselective hydrolysis of an epoxide to the corresponding enantiomerically enriched diol and unreacted epoxide $(66,67)$. The (S)-epoxide 77 [Scheme 15A] is a key intermediate in the synthesis of a number of prospective drug candidates (68). The enantiospecific hydrolysis of the racemic 1 -[2',3'-dihydro benzo(b)furan-4'-yl]-1,2-oxirane 77 to the corresponding (R)-diol 78 and unreacted $S$-epoxide 77 was demonstrated by Goswami et al. (69). Among cultures evaluated, two Aspergillus niger strains (SC 16310, SC 16311) and Rhodotorula glutinis SC 16239 selectively hydrolyzed the $(R)$-epoxide, leaving behind the $(S)$-epoxide 77 in greater than $95 \%$ e.e. and $45 \%$ yield (maximum yield is $50 \%$ ). Solvents had significant effects on both the extent of hydrolysis and the e.e. of unreacted (S)-epoxide 77. Most solvents gave a lower e.e. product and slower reaction rate than those of reactions without any solvent supplement. MTBE (15\% volume fraction) gave a reaction yield of $45 \%$ (theoretical maximum yield $50 \%$ ) and an e.e. of $99.9 \%$ for unreacted (S)-epoxide 77.

\section{Biocatalytic Dynamic Kinetic Resolution of $(R, S)-1-\left[2^{\prime}, 3^{\prime}\right.$ dihydroenzo(b)furan-4'-yl]- -ethane-1,2-diol}

Most commonly used biocatalytic kinetic resolutions of racemates often provide compounds with high e.e., however, the maximum theoretical yield of product is only $50 \%$. In many cases, the reaction mixture contains an approximately 50:50 mixture of reactant and product. The reactant and product often possess only slight differences in physical properties (e.g. a hydrophobic alcohol and its acetate), and thus separation may be very difficult. These issues with kinetic resolutions can be addressed by employing a »dynamic kinetic resolution«

$[A]$

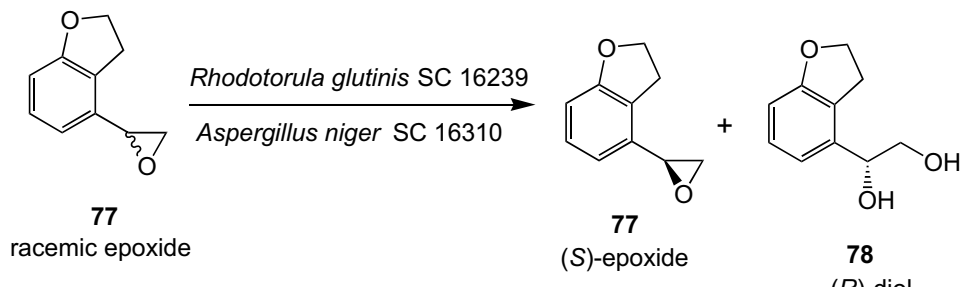

$[\mathrm{B}]$<smiles>OC[C@@H](O)c1cccc2c1CCO2</smiles>

78 $(R, S)$-diol<smiles>OCC(O)c1cccc2c1CCO2</smiles>

78

(S)-diol
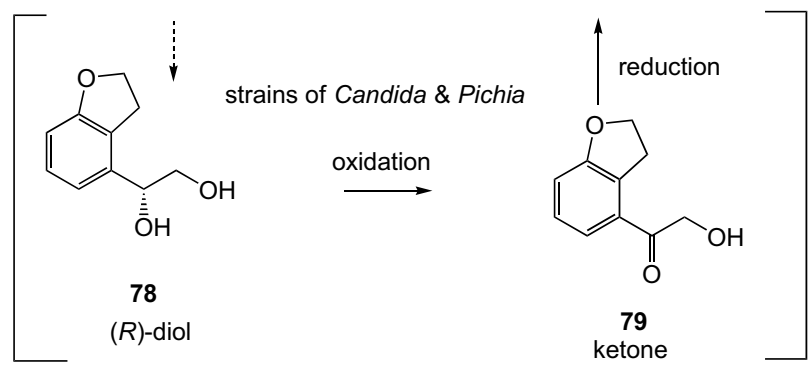

Scheme 15. (A) Synthesis of chiral intermediates for a melatonin receptor agonist: enantioselective microbial hydrolysis of racemic epoxide 77 to the corresponding (R)-diol 78 and unreacted (S)-epoxide 77. (B) Stereoinversion of racemic diol 78 to $(S)$-diol 78 by Candida boidinii and Pichia methanolica 
process involving a biocatalyst or biocatalyst with metal-catalyzed in situ racemization $(70,71)$.

(S)-1-[2',3'-dihydrobenzo(b)furan-4'-yl]-ethane-1,2-diol 78 [Scheme $15 B]$ is a potential precursor of $(S)$-epoxide 77 (68). The dynamic kinetic resolution of the racemic diol $\mathbf{7 8}$ to the $(S)$-enantiomer $\mathbf{7 8}$ has been demonstrated (72) by strains of Candida boidinii, Pichia methanolica, and Hansenula polymorpha. During biotransformation, the relative proportion of (S)-diol $\mathbf{7 8}$ increased with time and, at the end of one week, the e.e. obtained with these microorganisms was in the range of 87-100 \% (yield 60-75 $\%)$. A new compound was formed during these biotransformations and was identified as the hydroxy ketone $\mathbf{7 9 .}$ The area of the HPLC peak for hydroxy ketone first increased with time, reached a maximum, and then decreased, as expected for the proposed dynamic kinetic resolution pathway. C. boidinii SC 13822, C. boidinii SC 16115 , and P. methanolica SC 13860 transformed the racemic diol 78 in 3-4 days to (S)-diol 78 in yields of $62-75$ $\%$ and e.e.'s of $90-100 \%$.

\section{ß3-Receptor Agonists}

$\beta 3$-Adrenergic receptors are found on the cell surface of both white and brown adipocytes and are responsible for lipolysis, thermogenesis, and relaxation of intestinal smooth muscle (73). Consequently, several research groups are engaged in developing selective $\beta 3$ agonists for the treatment of gastrointestinal disorders, type II diabetes, and obesity $(74,75)$. Three different biocatalytic approaches for synthesis of chiral intermediates required for the total synthesis of $\beta 3$ receptor agonists 80 [Scheme 16A] have been investigated (76).

\section{Microbial reduction of 4-benzyloxy-3- -methanesulfonylamino-2'-bromoacetophenone}

The microbial reduction of 4-benzyloxy-3-methanesulfonylamino-2'-bromoacetophenone 81 [Scheme 16B] to the corresponding $(R)$-alcohol 82 has been demonstrated (76) using Sphingomonas paucimobilis SC 16113. The growth of S. paucimobilis SC 16113 was carried out

$[\mathrm{A}]$<smiles></smiles>

$\beta 3$-receptor agonist $\mathbf{8 0}$

$[\mathrm{B}]$

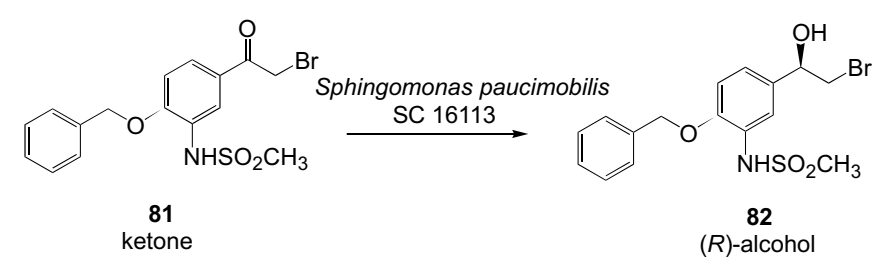

$[\mathrm{C}]$

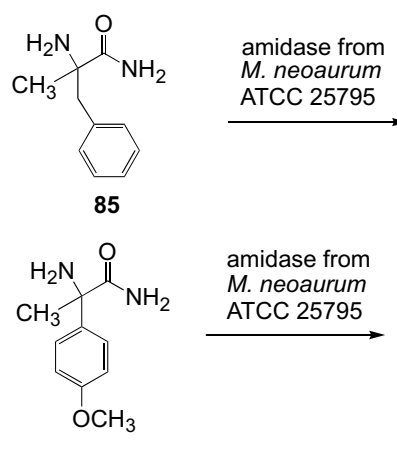

86

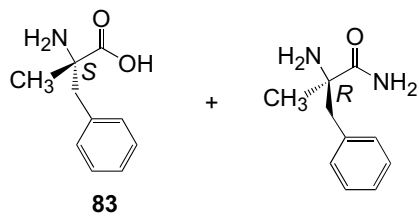

83

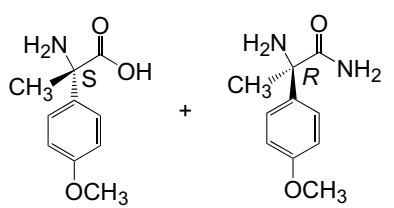

84

(D)

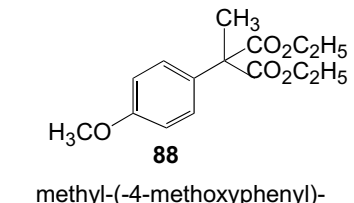

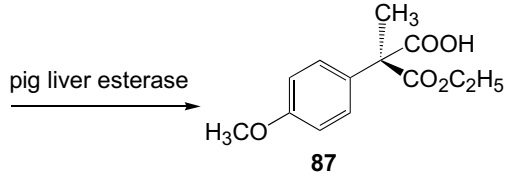

(S)-monoester

Scheme 16. (A) Enzymatic synthesis of chiral synthon for $\beta 3$-receptor agonist 80. (B) Enantioselective reduction of 4-benzyloxy-3-methanesulfonylamino-2'-bromoacetophenone 81 to $(R)$-alcohol 82. (C) Enantioselective hydrolysis of $\alpha$-methyl phenylalanine amide 85 and $\alpha$-methyl-4-methoxyphenylalanine amide 86 by amidase. (D) Enantioselective enzymatic hydrolysis of methyl-(4-methoxyphenyl)-propanedioic acid ethyl diester 88 to $(S)$-monoester 87 
in a $750-\mathrm{L}$ fermentor and cells $(60 \mathrm{~kg})$ harvested from the fermentor were used to conduct the biotransformation in $10-\mathrm{L}$ and $200-\mathrm{L}$ preparative batches. The cells were suspended in $80 \mathrm{mM}$ potassium phosphate buffer ( $\mathrm{pH}=6.0$ ) at $m / V=20 \%$ (wet cells) concentration, supplemented with compound 81 (2 g/L) and glucose $(25$ $\mathrm{g} / \mathrm{L})$, and the reduction was carried out at $37{ }^{\circ} \mathrm{C}$. In some batches, the fermentation broth was concentrated 3 -fold by microfiltration and subsequently washed with buffer by diafiltration and used directly in the bioreduction process. In all the batches, reaction yields of greater than $85 \%$ and e.e.'s of greater than $98 \%$ were obtained. The isolation of alcohol 82 from the 200-L batch gave $320 \mathrm{~g}$ (80\% yield) of product with an e.e. of $99.5 \%$.

In an alternate process, $200 \mathrm{~g}$ of frozen cells of $S$. paucimobilis SC 16113 were suspended in $1 \mathrm{~L}$ of $80 \mathrm{mM}$ potassium phosphate buffer $(\mathrm{pH}=6.0)$ and supplied with $10 \mathrm{~g}$ of substrate adsorbed on $50 \mathrm{~g}$ of hydrophobic resin XAD-16. In this process, an average reaction yield of 85 $\%$ and an e.e. of greater than $99 \%$ were obtained for alcohol 82. The product formed was adsorbed on to XAD-16 resin. At the end of the biotransformation, the reaction mixture was filtered on a 100-mesh $(150 \mu \mathrm{m})$ stainless steel screen, and the resin retained by the screen was washed with water. The product was then desorbed from the resin with acetonitrile and crystallized, giving an overall $x=75 \%$ yield and $99.8 \%$ e.e.

\section{Enzymatic resolution of racemic $\alpha-$ methyl phenylalanine amides}

The chiral amino acids 83 and 84 [Scheme 16C] are intermediates for the synthesis of $\beta 3$-receptor agonists $(74,75)$. These are available via the enzymatic resolution of racemic $\alpha$-methyl phenylalanine amide 85 and $\alpha$-methyl-4-methoxyphenylalanine amide 86 , respectively, by an amidase from Mycobacterium neoaurum ATCC 25795 (76). Wet cells $(m / V=10 \%)$ completed reaction of amide 85 in 75 min with a yield of $x=48 \%$ (theoretical max. 50 $\%$ ) and an e.e. of $95 \%$ for the desired (S)-amino acid 83 . Alternatively, freeze-dried cells were suspended in 100 $\mathrm{mM}$ potassium phosphate buffer $(\mathrm{pH}=7.0)$ at $1 \%$ concentration to give complete reaction in $60 \mathrm{~min}$ with a yield of $x=49.5 \%$ (theoretical max. $50 \%$ ) and an e.e. of $99 \%$ for the $(S)$-amino acid 83.

Freeze-dried cells of M. neoaurum ATCC 25795 and partially purified amidase (amidase activity in cell ex- tracts purified 5-fold by diethyl aminoethyl celluose column chromatography) were used for the biotransformation of compound 86. A reaction yield of $x=49 \%$ and an e.e. of $78 \%$ were obtained for the desired product 84 using freeze-dried cells. The reaction was completed in $50 \mathrm{~h}$. Using partially purified amidase, a reaction yield of $x=49 \%$ and an e.e. of $94 \%$ were obtained after $70 \mathrm{~h}$.

\section{Enantioselective hydrolysis of diethyl methyl-(4-methoxyphenyl)-propanedioate}

The (S)-monoester 87 [Scheme 16D] is a key intermediate for the synthesis of $\beta 3$-receptor agonists. The enantioselective enzymatic hydrolysis of diester 88 to the desired acid ester 87 by pig liver esterase (76) has been demonstrated. In various organic solvents the reaction yields and e.e. of monoester 87 depended upon the solvent used. High e.e.'s (>91 \%) were obtained with methanol, ethanol, and toluene as a co-solvent. Ethanol gave the highest reaction yield $(96.7 \%)$ and e.e. (96 \%) for the desired acid ester 87.

The e.e. of the $(S)$-monoester 87 was increased by decreasing the temperature from $25{ }^{\circ} \mathrm{C}$ to $10{ }^{\circ} \mathrm{C}$, when biotransformation was conducted in a biphasic system using ethanol as a co-solvent. A semi-preparative hydrolysis (30 g scale) was carried out using $10 \%$ ethanol as a co-solvent in a 3-L reaction mixture $(\mathrm{pH}=7.2)$ at $10{ }^{\circ} \mathrm{C}$ for $11 \mathrm{~h}$. A reaction yield of $x=96 \%$ and an e.e. of $96.9 \%$ were obtained. From the reaction mixture, $26 \mathrm{~g}(x=86 \%$ overall yield) of (S)-monoester 87 of $96.9 \%$ e.e. was isolated.

\section{Cholesterol Lowering Agents}

\section{Hydroxy methyl glutaryl CoA reductase inhibitors}

Reduction of 4-chloro-3-oxobutanoic acid methyl ester

The reduction of 4-chloro-3-oxobutanoic acid methyl ester 89 to $S$-(-)-4-chloro-3-hydroxybutanoic acid methyl ester 90 [Scheme 17] has been carried out with cell suspensions of Geotrichum candidum SC 5469. (S)-90 is a key chiral intermediate in the total chemical synthesis of 91, a cholesterol antagonist that acts by inhibiting HMG CoA reductase (77). In the biotransformation process, a reaction yield of $95 \%$ and e.e. of $96 \%$ were obtained for (S)-90 by glucose-, acetate- or glycerol-grown cells $(m / V=10 \%)$ of G. candidum SC 5469 at $10 \mathrm{~g} / \mathrm{L}$ of sub-
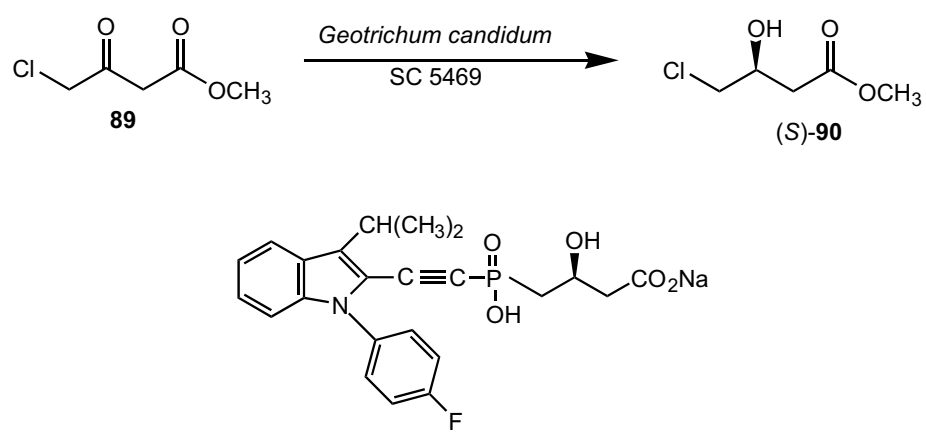

91

HMG-CoA reductase inhibitor

Scheme 17. Synthesis of a chiral synthon for the cholesterol-lowering drug 91: enantioselective microbial reduction of 4-chloro-3-oxobutanoic acid methyl ester 89 to $(S)$-4-chloro-3-hydroxybutanoic acid ester 90 
strate input. The e.e. of (S)-90 was increased to $98 \%$ by heat-treatment of cell-suspensions $\left(55{ }^{\circ} \mathrm{C}\right.$ for $30 \mathrm{~min}$ ) prior to conducting the bioreduction of 89 .

Reduction of ethyl 4-chloroacetoacetate

In an alternate approach, the asymmetric reduction of ethyl 4-chloroacetoacetate to (S)-4-chloro-3-hydroxybutonoate was demonstrated by a secondary alcohol dehydrogenase (PfODH) from Pichia finlandica. The gene encoding PfODH was cloned from $P$. finlandica and over-expressed in Escherichia coli. Formate dehydrogenase was used to regenerate cofactor NADH required for this reaction. The recombinant E. coli, co-expressing both PfODH and formate dehydrogenase from Mycobacterium sp., produced (S)-4-chloro-3-hydroxybutanoate in $98.5 \%$ yield and $99 \%$ e.e. at $32 \mathrm{~g} / \mathrm{L}$ of substrate input (78).

Preparation of (R)-4-cyano-3-hydroxybutyrate

An enzymatic process was developed for the preparation of 4-halo-3-hydroxybutyric acid derivatives by ketoreductase-catalyzed conversion of 4-halo-3-ketobutyric acid derivatives. Thus the genes encoding halohydrin dehydrogenase from Agrobacterium tumefaciens, ketoreductase from Candida magnoliae, glucose dehydrogenase from Bacillus subtilis and formate dehydrogenase from Candida boidinii were separately cloned into Escherichia coli BL21. Each enzyme was produced by fermentation, isolated and characterized. Then ethyl (R)-4-cyano-3-hydroxybutyrate was prepared from ethyl 4-chloroacetoacetate by the following procedure. Ethyl 4-chloroacetoacetate was incubated at $\mathrm{pH}=7.0$ with ketoreductase and glucose dehydrogenase and NADP for $40 \mathrm{~h}$ to produce ethyl (S)-chloro-3-hydroxybutyrate. The ethyl (S)-chloro-3-hydroxybutyrate was extracted with ethyl acetate, dried, filtered and concentrated to yield a $\approx 97 \%$ pure ester. The dried ethyl (S)-chloro-3-hydroxybutyrate was dissolved in phosphate buffer and mixed with halohydrin dehalogenase and sodium cyanide at $\mathrm{pH}=8.0$. After
$57 \mathrm{~h}$ reaction, essentially pure $(R)$-4-cyano-3-hydroxybutyrate was recovered, which is an intermediate used in the synthesis of many HMG-CoA reductase inhibitors (79).

Preparation of $(R)$ - and (S)-ethyl-3-hydroxybutyrate

An efficient two-step enzymatic process for production of $(R)$ - and (S)-ethyl-3-hydroxybutyrate (HEB) was developed and scaled-up to a multikilogram scale. Both enantiomers were obtained at $99 \%$ chemical purity and over $96 \%$ e.e., with an overall process yield of $73 \%$. The first reaction involved an acetylation of racemic HEB with vinyl acetate for the production of (S)-HEB. In the second reaction, $(R)$-enriched ethyl-3-acetoxybutyrate (AEB) was subjected to alcoholysis with ethanol to derive optically pure (R)-HEB. Immobilized Candida antarctica lipase B (CALB) was employed in both stages, with high productivity and selectivity. The type of butyric acid ester influenced the enantioselectivity of the enzyme. Thus, extending the ester alkyl chain from ethyl to octyl resulted in a decrease in e.e., whereas using bulky groups, such as benzyl or t-butyl, improved the enantioselectivity of the enzyme. The immobilized enzyme was packed in a column and the reactants were circulated through the enzyme bed until the targeted conversion was reached. The desired products were separated from the reaction mixture in each of the two stages by fractional distillation. The main features of the process are the exclusion of solvent (thus ensuring high process throughput) and the use of the same enzyme for both the acetylation and the alcoholysis steps to prepare kilogram quantities of (S)-HEB and (R)-HEB (80).

Enzymatic reduction of 3,5-dioxo-6-(benzyloxy) hexanoic acid, ethyl ester

The enantioselective reduction of a diketone, 3,5-dioxo-6-(benzyloxy) hexanoic acid ethyl ester 92 , to $(3 R, 5 S)$ -dihydroxy-6-(benzyloxy) hexanoic acid ethyl ester 93a [Scheme 18] has been demonstrated by cell suspensions of Acinetobacter calcoaceticus SC 13876 (81). Compound 93a is a key chiral intermediate required for the chemi-<smiles>CCOC(=O)CC(=O)CC(=O)COc1ccccc1</smiles>

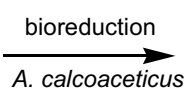

SC 13876

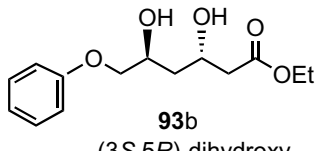

$(3 S, 5 R)$-dihydroxy

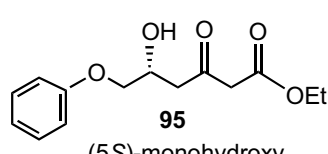

(5S)-monohydroxy
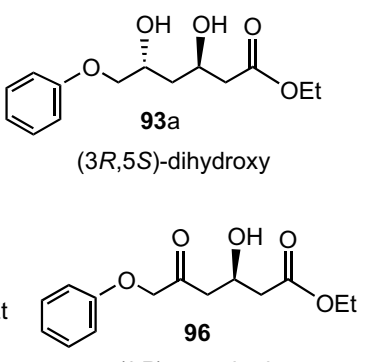

(3R)-monohydroxy<smiles>CN(C)C(=N)/C(=C\C=C\C1C[C@@H](O)CC(=O)O1)c1ccc(F)cc1</smiles>

HMG COA reductase inhibitor

Scheme 18. Synthesis of a chiral synthon for the cholesterol lowering drug 94: enantioselective microbial reduction of 3,5-dioxo-6-(benzyloxy) hexanoic acid, ethyl ester 92 to $(3 R, 5 S)$-dihydroxy-6-(benzyloxy) hexanoic acid, ethyl ester 93a 
cal synthesis of $\{4-[4 \alpha, 6 \beta(E)]\}-6-[4,4-$ bis-(4-fluorophenyl)-3-(1-methyl-1H-tetrazol-5-yl)-1,3-butadienyl]-tetrahydro-4-hydroxy-2H-pyren-2-one 94, an anticholesterol drug that acts by inhibition of HMG CoA reductase (82). A reaction yield of $85 \%$ and an e.e. of $97 \%$ were obtained using glycerol-grown cells at $2 \mathrm{~g} / \mathrm{L}$. Cell extracts of $A$. calcoaceticus SC 13876 in the presence of $\mathrm{NAD}^{+}$, glucose and glucose dehydrogenase reduced 92 to the corresponding monohydroxy compounds [3-hydroxy-5-oxo-6-(benzyloxy) hexanoic acid ethyl ester 96 and 5-hydroxy-3-oxo-6-(benzyloxy) hexanoic acid ethyl ester 95]. Both 95 and 96 were further reduced to the $(3 R, 5 S)$-dihydroxy compound 93 a by cell extracts. A reaction yield of $92 \%$ and an e.e. of $98 \%$ were obtained at $10 \mathrm{~g} / \mathrm{L}$ of substrate input.

Enzymatic preparation of a 2,4-dideoxyhexose derivative

The chiral 2,4-dideoxyhexose derivative required for the HMG CoA reductase inhibitors has also been prepared using 2-deoxyribose-5-phosphate aldolase (DERA). As shown in Scheme 19, the reactions start with a stereospecific addition of acetaldehyde 97 to a substituted acetaldehyde to form a 3-hydroxy-4-substituted butyraldehyde 98, which reacts subsequently with another acetaldehyde to form a 2,4-dideoxyhexose derivative 99. DERA has been expressed in Escherichia coli (83).

The above process has been improved and optimized for production of key intermediates for the common chiral side chain of cholesterol-lowering drugs such as Lipitor (atorvastatin) and Crestor (rosuvastatin). An improvement of almost 400-fold in volumetric produc- tivity relative to the published enzymatic reaction conditions has been achieved, resulting in an attractive process that has been run on up to a 100-g scale in a single batch at a rate of $30.6 \mathrm{~g} \mathrm{~L}^{-1} \mathrm{~h}^{-1}$. Catalyst load has been improved by 10 -fold as well, from $w=20$ to $2.0 \%$ DERA. These improvements were achieved by a combination of discovery from environmental DNA of DERA with improved activity and reaction optimization to overcome substrate inhibition. The two stereogenic centers are set by DERA with enantiomeric excess at greater than 99.9 $\%$ and diastereomeric excess at $96.6 \%$. In addition, downstream chemical processes have been developed to convert the enzyme product efficiently to versatile intermediates applicable to preparation of atorvastatin and rosuvastatin (84).

\section{Calcium Channel Antagonist}

Enzymatic synthesis of [(3R-cis)-1,3,4,5-tetrahydro-3-hydroxy-4-(4-methoxyphenyl)-6-(trifluoromethyl)-2 H-1-benzazepin-2-one]

Diltiazem 100 [Scheme 20], a benzothiazepinone calcium channel-blocking agent that inhibits influx of extracellular calcium through L-type voltage-operated calcium channels, has been widely used clinically in the treatment of hypertension and angina (85). Since diltiazem has a relatively short duration of action (86), an 8-chloroderivative has recently been introduced into the clinic as a more potent analogue (87). Lack of extended duration of action and little information on structure-activity relationships in this class of compounds led Floyd et al.
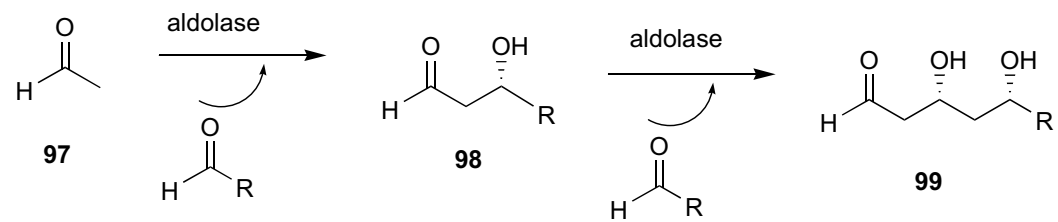

Scheme 19. Enzymatic synthesis of 2,4-dideoxyhexose derivative 99, a chiral synthon for cholesterol lowering drugs

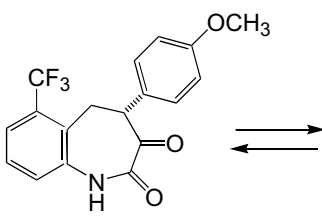

103<smiles>CCNCCN1C(=O)C(O)C(c2ccc(OC)cc2)Sc2c1cccc2C(F)(F)F</smiles>

Diltiazem 100<smiles>COc1ccc(C2Cc3c(C)cccc3NC(=O)C2O)cc1</smiles><smiles>COc1ccc(C2Cc3c(cccc3C(F)(F)F)NC(=O)C2=O)cc1</smiles>

103

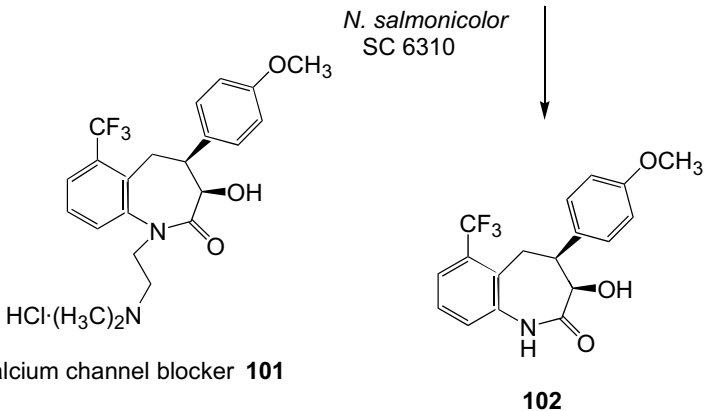

Scheme 20. Synthesis of chiral synthon for calcium channel blocker 101: microbial reduction of 4,5-dihydro-4-(4-methoxyphenyl)-6-(trifluoromethyl)-1H-benzazepin-2,3-dione 103 
(88) to prepare isosteric 1-benzazepin-2-ones; this led to the identification of [(cis)-3-(acetoxy)-1-[2-(dimethylamino)ethyl]-1,3,4,5-tetrahydro-4-(4-methoxyphenyl)-6-trifluoromethyl)-2H-1-benzazepin-2-one] 101 as a longer lasting and more potent antihypertensive agent. A key intermediate in the synthesis of this compound was [(3R-cis)-1,3,4,5-tetrahydro-3-hydroxy-4-(4-methoxyphen yl)-6-(trifluoromethyl)-2H-1-benzazepin-2-one] 102. An enantioselective microbial process [Scheme 20] was developed for the reduction of 4,5-dihydro-4-(4-methoxyphenyl)-6-(trifluoromethyl)-1H-1-benzazepin-2,3-dione 103, which exists predominantly in the achiral enol form in rapid equilibrium with the two enantiomeric keto forms. Reduction of $\mathbf{1 0 3}$ could give rise to formation of four possible alcohol stereoisomers. Remarkably, conditions were found under which only the single alcohol isomer 102 was obtained. Among various cultures evaluated, microorganisms from the genera Nocardia, Rhodococcus, Corynebacterium, and Arthobacter reduced compound 103 with $60-70 \%$ conversion. The most effective culture, Nocardia salmonicolor SC 6310, catalyzed the bioconversion of $\mathbf{1 0 3}$ to $\mathbf{1 0 2}$ in $96 \%$ reaction yield with $99.8 \%$ e.e. A preparative-scale fermentation process for growth of $N$. salmonicolor and a bioreduction process using cell suspensions of the organism were demonstrated (89).

\section{Asymmetric hydrolysis of 1,4-dihydropyridine diesters}

Streptomyces viridosporus A-914 was screened as a producer of an enzyme that effectively forms chiral intermediates of 1,4-dihydropyridine calcium antagonists (90). The supernatant liquid of the growing culture of this strain exhibited high activity for enantioselective hydrolysis of prochiral 1,4-dihydropyridine diesters to the corresponding $(4 R)$ half esters. The responsible enzyme (termed DHP-A) was purified to homogeneity and characterized. Cloning and sequence analysis of the gene for DHP-A (dhpA) revealed that the enzyme was a serine protease that is highly similar in both structural and enzymatic features to SAM-P45. Homologous or heterologous expression of dhpA resulted in overproduction of the enzyme in culture supernatants, with 2.4- to 4.2-fold higher specific activities than in the parent $S$. viridosporus A-914 (90).

\section{Enantioselective Enzymatic Cleavage of the Carbobenzyloxy (Cbz) Group}

Amino groups often require protection during synthetic transformations elsewhere in the molecule; at some point, the protecting group must be removed. Enzymatic protection and de-protection under mild conditions have been demonstrated previously. Penicillin G amidase and phthalyl amidase have been used for the enzymatic de-protection of the phenylacetyl and phthaloyl groups from the corresponding amido or imido compounds $(90,91)$. Acylases have been used widely in the enantioselective de-protection of $\mathrm{N}$-acetyl-DL-amino acids (92). Enzymatic de-protection of N-carbamoyl L-amino acids and $\mathrm{N}$-carbamoyl D-amino acids has been demonstrated for microbial L-carbamoylases and D-carbamoylases, respectively $(93,94)$.
The carbobenzyloxy $(\mathrm{Cbz})$ group is commonly used to protect amino and hydroxyl groups during organic synthesis. Chemical de-protection is usually achieved by hydrogenation with a palladium catalyst $(95,96)$. However, during chemical de-protection, some groups are reactive under the hydrogenolysis conditions (e.g. carbon-carbon double bonds) or may interfere with hydrogenolysis (e.g. thiols or sulfides). An enantioselective enzymatic de-protection process has been developed that can be performed under mild conditions without damaging any otherwise susceptible groups in the molecule. A microbial culture was isolated from soil and identified as Sphingomonas paucimobilis strain SC 16113; this culture catalyzed the enantioselective cleavage of Cbz-groups from various Cbz-protected amino acids (97). Only Cbz-L-amino acids were de-protected, giving complete conversion to the corresponding L-amino acid. Cbz-D-amino acids gave $<2 \%$ reaction yield.

Racemic Cbz-amino acids were also evaluated as substrates for hydrolysis by cell extracts of $S$. paucimobilis SC 16113. As anticipated, only the L-enantiomer was hydrolyzed, giving the L-amino acids in greater than $48 \%$ yields and greater than $99 \%$ e.e.'s. The unreacted Cbz-D-amino acids were recovered in greater than $48 \%$ yield and greater than $98 \%$ e.e. (97). Cbz-cleaving enzyme has been purified and over-expressed in Escherichia coli (98).

\section{Tryptase Inhibitor}

$(R, S)-\mathrm{N}$-(t-butoxycarbonyl)-3-hydroxymethylpiperidine 104 [Scheme 21] is a key intermediate in the synthesis of a potent tryptase inhibitor (99). (S)-104 was made from $(R, S)$-3-hydroxy methylpiperidine via fractional crystallization of the corresponding L(-)-dibenzoyl tartarate salt followed by hydrolysis and esterification (100). Lipase from Pseudomonas cepacia was the best enzyme for the stereospecific resolution of $R, S-\mathrm{N}$-(t-butoxycarbonyl)-3-hydroxymethylpiperidine 104. (S)-104 was obtained in $16 \%$ yield and greater than $95 \%$ e.e. by hydrolysis of $R, S$-acetate by lipase from $P$. cepacia. Lipase PS-30 also catalyzed esterification of the $(R, S)-\mathrm{N}$-(t-butoxycarbonyl)-3-hydroxymethylpiperidine $\mathbf{1 0 4}$ with succinic anhydride 105 to yield $(R)-\mathrm{N}$-(t-butoxycarbonyl)-3-hydroxy methylpiperidine 104 and the (S)-hemisuccinate ester 106, which could be easily separated and hydrolyzed by base to the (S)-104. The yield and e.e. could be improved greatly by repeating the process. Using the repeated esterification procedure, (S)-104 was obtained in $32 \%$ yield (maximum theoretical yield $50 \%$ ) and $98.9 \%$ e.e. (101).

\section{Acyloin and Aldol Condensation}

Asymmetric $\alpha$-hydroxyketones (acyloin) are important classes of intermediates in organic synthesis due to their bi-functional aspect, especially having one chiral center amenable to further modification. Enzyme-mediated acyloin formation could provide an advantageous, environmentally-friendly method of preparing optically active asymmetric acyloins (102). Acyloin formations mediated by yeast pyruvate decarboxylase (103) and bacterial benzoylformate decarboxylase (104) have been reported. Though phenylpyruvate decarboxylase (PPD) 


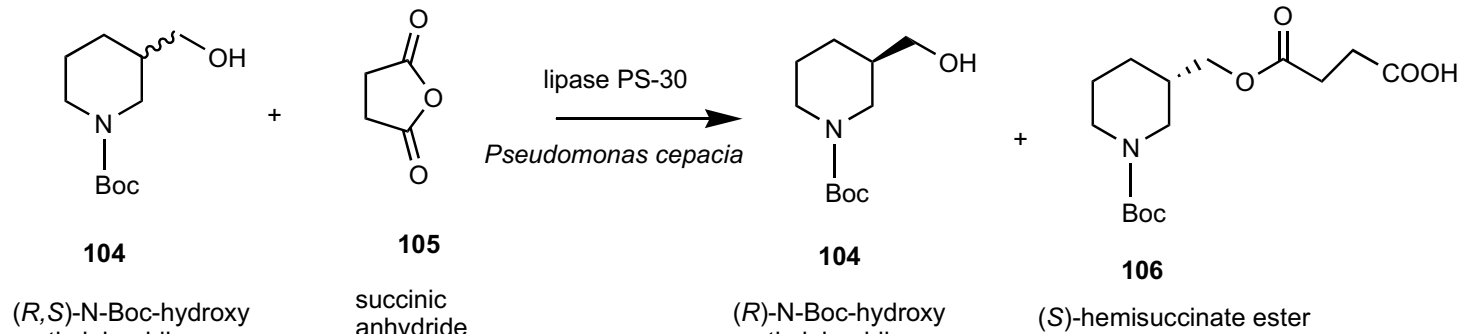

(S)-hemisuccinate ester

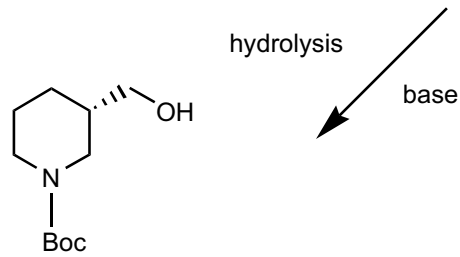

104

(S)-N-Boc-hydroxy methylpiperidine

Scheme 21. Preparation of a chiral synthon for a tryptase inhibitor: enzymatic resolution of racemic (t-butoxycarbonyl)-3-hydroxymethylpiperidine 104 to (S)-104

for decarboxylation of phenylpyruvic acid was known for a long time (102), recently we reported the acyloin condensation catalyzed by PPD (105). Achromobacter eyrydice PPD was used to catalyze the asymmetric acyloin condensation of phenylpyruvate 107 with various aldehydes 108 to produce optically active acyloins $\mathrm{PhCH}_{2}$ $\mathrm{COCH}(\mathrm{OH}) \mathrm{R} 109$ [Scheme 22]. The acyloin condensation yield decreased with increasing chain length for straight chain aliphatic aldehydes from $76 \%$ for acetaldehyde to $24 \%$ for valeraldehyde. The e.e.'s of the acyloin products were 87-98\%. Low yields of acyloin products were obtained with chloro acetaldehyde $(13 \%)$ and glyco aldehyde (16\%). Indole-3-pyruvate was a substrate of the enzyme and provided acyloin condensation product 3-hydroxy-1-(3-indolyl)-2-butanone $\mathbf{1 1 0}$ with acetaldehyde in $19 \%$ yield. PPD has been purified from Achromobacter eyrydice. The purified protein was shown to be of 150 $\mathrm{kD}$ molecular weight and to consist of two subunits, one of $90 \mathrm{kD}$ and one of $40 \mathrm{kD}$ (106).

\section{NK1/NK2 Dual Antagonist}

Tachykinins are a group of biologically active neuropeptide hormones that are widely distributed throughout the nervous system. They are implicated in a variety of biological processes such as pain transmission, inflammation, vasodilatation and secretion (107). The effect of Tachykinins is modulated via the specific G-protein coupled receptors like NK1 and NK2. Thus non-peptide NK-receptor antagonists are potentially useful in the treatment of a variety of chronic diseases including asthma, bronchospasm, arthritis, and migraine $(108,109)$. The structure-activity relationship of several non-peptide NK1/NK2 antagonists has led to the discovery of a new class of oxime-based dual antagonist $(110,111)$, namely compound 111 [Scheme 23]. The biological activity of $\mathbf{1 1 1}$ resides mainly in the $R, R$-diastereomers. An enzymatic process for desymmetrization of the prochiral diethyl 3-(3',4'-dichlorophenyl)-glutarate 112 to the cor-<smiles>O=C(O)C(=O)OCc1ccccc1</smiles>

108 and $109(\mathrm{R})$ : a (Me), b (Et), c (n-Pr), d (n-Bu), e $\left(\mathrm{PhCH}_{2}\right), \mathrm{f}(\mathrm{Ph}), \mathrm{g}(\mathrm{H})$, h $\left(\mathrm{Me}\left(\mathrm{CH}_{2}\right)_{6}\right)$, i $\left(\mathrm{Me}\left(\mathrm{CH}_{2}\right)_{8}\right)$, j $\left(\mathrm{Me}\left(\mathrm{CH}_{2}\right)_{10}\right), \mathrm{k}(\mathrm{PhCH}=\mathrm{CH}), \mathrm{I}\left(\mathrm{Br}_{3} \mathrm{C}\right), \mathrm{m}\left(\mathrm{Me}_{2} \mathrm{CH}\right)$, n $\left(\mathrm{Me}_{3} \mathrm{CCH}_{2}\right)$, o $\left(\mathrm{BrCH}_{2}\right), \mathrm{p}\left(\mathrm{BrCH}_{2} \mathrm{CH}_{2}\right), \mathrm{q}\left(\mathrm{CH}_{2}=\mathrm{CH}\right), \mathrm{r}\left(\mathrm{ClCH}_{2}\right)$, s $\left(\mathrm{HOCH}_{2}\right)$<smiles>[R]C(O)C(=O)Cc1ccccc1</smiles><smiles>C[C@@H](O)C(=O)Cc1c[nH]c2ccccc12</smiles>

110

Scheme 22. Enzymatic asymmetric acyloin condensation reactions catalyzed by phenylpyruvate decarboxylase 
<smiles>CCOC(=O)CC(CC(=O)OCC)c1ccc(Cl)c(Cl)c1</smiles>

diester

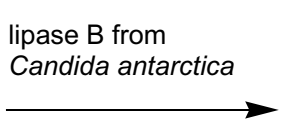<smiles>CCOC(=O)C[C@H](S)c1ccc(Cl)c(Cl)c1</smiles>

113

(S)-monoester<smiles>[R][C@]1(CC(C)=O)CCCN(C2CCN(CC[C@@H](/C(CN(C)C(=O)c3cc(Cl)cc(Cl)c3)=N/OC)c3ccc(Cl)c(Cl)c3)CC2)C1=O</smiles>

111

Scheme 23. Preparation of a chiral synthon for an NK1/NK2 dual antagonist: enzymatic asymmetric hydrolysis of diethyl 3-(3',4'-dichlorophenyl)-glutarate $\mathbf{1 1 2}$ to the corresponding (S)-monoester $\mathbf{1 1 3}$

responding (S)-monoester $\mathbf{1 1 3}$ has been developed using lipase B from Candida antarctica in either free or immobilized forms. At $100 \mathrm{~g} / \mathrm{L}$ of substrate input, a reaction yield of $97 \%$ and e.e. of greater than $99 \%$ were obtained for desired (S)-monoester. The process was scaled up to produce $200 \mathrm{~kg}$ of product in overall $80 \%$ yield (112). DNA family shuffling was used to create chimeric lipase B protein with improved activity towards diethyl3-(3',4'-dichlorophenyl)-glutarate. Three homologous lipases from Candida antarctica ATCC 32657, Hyphozyma sp. CBS 648.91 and Cryptococcus tsukubaensis ATCC 24555 were cloned and shuffled to generate a diverse gene library and, using a high-throughput screening assay, a chimeric lipase B protein having 20-fold higher activity towards substrate was identified (113). The thermostability of lipase was also improved by directed evolution (114).

\section{References}

1. Food \& Drug Administration: FDA's statement for the development of new stereoisomeric drugs, Chirality, 4 (1992) 338-340.

2. B. Buckland, D. Robinson, M. Chartrain, Metab. Eng. 2 (2000) $42-80$.

3. J. Pesti, R. Dicosimo, Curr. Opin. Discov. Dev. 3 (2003) 884901.

4. M. Mahmoudian, Biocatal. Biotransform. 18 (2000) 105-116.

5. D. Stewart, Curr. Opin. Chem. Biol. 5 (2001) 120-129.

6. A. Zak, Curr. Opin. Chem. Biol. 5 (2001) 130-136.

7. R. Patel, Curr. Opin. Drug Discov. Dev. 3 (2003) 902-920.

8. R. Patel: Stereoselective Biocatalysis for Synthesis of Some Chiral Pharmaceutical Intermediates. In: Stereoselective Biocatalysis, R. N. Patel (Ed.), Marcel Dekker, New York (2000) pp. 87-130.

9. K. Yoshimura, R. Kato, M. F. Kavlick, A. Nguyen, V. Maroun, K. Maeda, K. Hussain, A. Ghosh, S. Gulnik, J. Erickson, H. Mitsuya, J. Virol. 76 (2002) 1349-1358.
10. A. Tomasselli, S. Thaisrivongs, R. Heinrikson, Advances in Antiviral Drug Design, 2 (1996) 173-228.

11. G. Bold, A. Fassler, H. Capraro, R. Cozens, T. Klimkait, J. Lazdins, J. Mestan, B. Poncioni, J. Rosel, D. Stover, M. Tintelnot-Blomley, F. Acemoglu, W. Beck, E. Boss, M. Eschbach, T. Hurlimann, E. Masso, S. Roussel, K. Ucci-Stoll, D. Wyss, M. Lang, J. Med. Chem. 41 (1998) 3387-3401.

12. B. Robinson, K. Riccardi, Y.-F. Gong, Q. Guo, D. Stock, W. Blair, B. Terry, C. Deminie, F. Djang, R. Colonno, P.-F. Lin, Antimicrob. Agents Chemother. 44 (2000) 2093-2099.

13. A. Fassler, G. Bold, H.-G. Capraro, H. Steiner, Tetrahedron Lett. 39 (1998) 4925-4928.

14. Z. Xu, J. Singh, M. Schwinden, B. Zheng, T. Kissick, B. Patel, M. Humora, F. Quiroz, L. Dong, D.-M. Hsieh, J. Heikes, M. Pudipeddi, M. Lindrud, S. Srivastava, D. Kronenthal, R. Mueller, Org. Proc. Res. Develop. 6 (2002) 323-328.

15. R. Patel, L. Chu, R. Mueller, Tetrahedron: Asymmetry, 14 (2003) 3105-3109.

16. J. Barrish, E. Gordon, M. Alam, P. Lin, G. Bisacchi, P. Cheng, A. Fritz, J. Greytok, M. Hermsmeier, W. Humphreys, K. Lis, M. Marella, Z. Merchant, T. Mitt, R. Morrison, M. Obermeier, J. Pluscec, M. Skoog, W. Slusarchyk, S. Spergel, J. Stevenson, C. Sun, J. Sundeen, P. Taunk, T. Tino, B. Warrack, R. Colono, R. Zahler, J. Med. Chem. 37 (1994) 1758-1771.

17. R. Patel, A. Banerjee, C. McNamee, D. Brzozowski, L. Szarka, Tetrahedron: Asymmetry, 8 (1997) 2547-2552.

18. M. Chartrain, B. Jackey, C. Taylor, V. Sandfor, K. Gbewonyo, L. Lister, L. Dimichele, C. Hirsch, B. Heimbuch, C. Maxwell, D. Pascoe, B. Buckland, R. Greasham, J. Ferment. Bioeng. 86 (1998) 550-558.

19. B. Buckland, D. Robinson, M. Chartrain, Metab. Eng. 2 (2000) 42-48.

20. M. Chartrain, P. Salmon, D. Robinson, B. Buckland, Curr Opin. Biotechnol. 11 (2000) 209-214.

21. N. Zhang, B. Stewart, J. Moore, R. Greasham, D. Robinson, B. Buckland, C. Lee, Metab. Eng. 2 (2000) 339-348.

22. A. Amanullah, C. Hewitt, A. Nienow, C. Lee, M. Chartrain, B. Buckland, S. Drew, J. Woodley, Biotechnol. Bioeng. 80 (2002) 239-249. 
23. C. Ireland, P. Leeson, J. Castaner, Drug. Future, 22 (1997) 359-370.

24. R. Hanson, Z. Shi, D. Brzozowski, A. Banerjee, T. Kissick, J. Singh, A. Pullockaran, J. North, J. Fan, J. Howell, S. Durand, M. Montana, D. Kronenthal, R. Mueller, R. Patel, Bioorg. Med. Chem. 8 (2000) 2681-2687.

25. S. Pianko, J. McHutchison, J. Gastroent. Hepatol. 15 (2000) 581-586.

26. P. Ferenci, H. Brunner, K. Nachbaur, C. Datz, M. Gschwantler, H. Hofer, R. Stauber, J. H. Franz, J. Wolfgang, R. Martha, M.-S. Petra, H. Karin, G. Alfred, V. Wolfgang, Hepatology, 34 (2001) 1006-1011.

27. S. Sauleda, A. Juarez, J. Esteban, C. Altisent, I. Ruiz, L. Puig, R. Esteban, J. Guardia, Hepatology, 34 (2001) 10351040

28. A. Chutaputti, J. Gastroent. Hepatol. 15 (2000) E156-E163.

29. H. Bonkovsky, D. Stefancyk, K. McNeal, B. Banner, Q. Liu, G. Zucker, J. Israel, J. Stagias, J. Colker, Dig. Dis. Sci. 46 (2001) 2051-2059.

30. M. Tamarez, B. Morgan, G. Wong, W. Tong, F. Bennett, R. Lovey, J. McCormick, A. Zaks, Org. Proc. Res. Develop. 7 (2003) 951-953.

31. G. Hoegenauer, Antibiotics, 5 (1979) 344-360.

32. H. Berner, H. Vyplel, G. Schulz, P. Stuchlik, Tetrahedron, 39 (1983) 1317-1321.

33. R. Hanson, J. Matson, D. Brzozowski, T. LaPorte, D. Springer, R. Patel, Org. Proc. Res. Develop. 6 (2002) 482-487.

34. D. Springer, M. Sorenson, S. Huang, T. Connolly, J. Bronson, J. Matson, R. Hanson, D. Brzozowski, T. LaPorte, R. Patel, Bioorg. Med. Chem. Lett. 13 (2003) 1751-1753.

35. M. Suffness, M. Wall: Taxol: Science and Application, M. Suffness (Ed.), CRC Press, New York (1995).

36. R. Holton, R. Biediger, P. Joatman: Semisynthesis of Taxol and Taxotere. In: Taxol: Science and Application, M. Suffness (Ed.), CRC Press, New York (1995) pp. 97-123.

37. D. Kingston: Natural Taxoids: Structure and Chemistry, In: Taxol: Science and Application, M. Suffness (Ed.), CRC Press, New York (1995) pp. 287-317.

38. E. Baldini, T. Prochilo, B. Salvadori, A. Bolognesi, D. Aldrighetti, M. Venturini, R. Rosso, F. Carnino, L. Gallo, P. Giannessi, P. Conte, C. Orlandini, P. Bruzzi, Br. J. Cancer, 91 (2004) 45-49.

39. P. Schiff, J. Fant, S. Horwitz, Nature, 277 (1979) 665-667.

40. R. Patel, Ann. Rev. Microbiol. 98 (1995) 361-395.

41. M. Wani, H. Taylor, M. Wall, P. Coggon, A. McPhail, J. Am. Oil Chem. Soc. 93 (1971) 2325-2327.

42. D. G. I. Kingston, A. A. Molinero, J. M. Rimoldi: The Taxane Diterpenoids. In: Progress in the Chemistry of Organic Natural Products, Vol. 61, W. Herz, H. Falk, G. W. Kirby (Eds.), Springer Verlag, Wien (1993) pp. 1-206.

43. M. Mattina, G. MacEachern, J. Chromatogr. 679 (1994) 269275.

44. R. Hanson, J. Wasylyk, V. Nanduri, D. Cazzulino, R. Patel, L. Szarka, J. Biol. Chem. 269 (1994) 22145-22149.

45. V. Nanduri, R. Hanson, T. LaPorte, R. Ko, R. Patel, L. Szarka, Biotechnol. Bioeng. 48 (1995) 547-550.

46. R. Hanson, J. Howell, D. Brzozowski, S. Sullivan, R. Patel, L. Szarka, Biotechnol. Appl. Biochem. 26 (1997) 153-158.

47. R. Patel, A. Banerjee, J. Howell, C. McNamee, D. Brzozowski, D. Mirfakhrae, V. Nanduri, J. Thottathil, L. Szarka, Tetrahedron: Asymmetry, 4 (1993) 2069-2084.

48. R. Patel, A. Banerjee, R. Ko, J. Howell, W-S Li, F. Comezoglu, R. Partyka, L. Szarka, Biotechnol. Appl. Biochem. 20 (1994) 23-33.

49. E. Baloglu, D. Kingston, J. Nat. Prod. 62 (1999) 1068-1071.
50. W. Rose, B. Long, C. Fairchild, F. Lee, J. Kadow, Clin. Cancer Res. 7 (2001) 2016-2021.

51. R. Patel, J. Howell, R. Chidambaram, S. Benoit, J. Kant, Tetrahedron: Asymmetry, 14 (2003) 3673-3677.

52. R. Hanson, R. Patel, Process for the Preparation of C-4 Deacetyltaxanes, WO 2000010989 A1 20000302 CAN 132:194525 AN 2000:144872, PCT Int. Appl. (2000) pp. 17.

53. H. Kagechika, E. Kawachi, Y. Hashimoto, K. Shudo, T. Himi, J. Med. Chem. 31 (1988) 2182-2192.

54. K. Shudo, H. Kagechika: Chemistry and Biology of Synthetic Retinoids, M. Dawson, W. Okamura (Eds.), CRC Press, Boca Raton (1989).

55. G. Morriss-Kay: Retinoids: Their Physiological Function and Therapeutic Potential. In: Advances in Organ Biology, Vol. 3, G. V. Sherber (Ed.), Elsevier Science (1997) 79-92.

56. R. Moon, L. Itri, Retinoids, 2 (1984) 327-331.

57. H. Kagechika, E. Kawachi, Y. Hashimoto, T. Himi, K. Shudo, J. Med. Chem. 31 (1988) 2182-1292.

58. M. Belema, F. Zusi, K. Tramposch, Active Enantiomer of RAR $\gamma$-Specific Agonist. WO 0016769 CAN 132:246379 AN 2000:209902, PCT Int. Appl. (2000) pp. 32.

59. R. Patel, L. Chu, R. Chidambaram, J. Zhu, J. Kant, Tetrahedron: Asymmetry, 12 (2002) 349-355.

60. D. Schenk, D. Games, P. Seubert, J. Mol. Neurosci. 17 (2001) 259-265.

61. J. Audia, T. Britton, J. Droste, B. Folmer, G. Huffman, V. John, H. Lee, T. Mabry, J. Nissen, WO 9822494 A2 19980528 CAN 129:41414, PCT Int. Appl. (1998).

62. R. Patel, A. Banerjee, V. Nanduri, A. Goswami, F. Comezoglu, J. Am. Oil Chem. Soc. 77 (2000) 1015-1019.

63. V. Nanduri, A. Banerjee, J. Howell, D. Brzozowski, R. Eiring, R. Patel, J. Ind. Microbiol. Biotechnol. 25 (2000) 171175.

64. V. Nanduri, R. Hanson, A. Goswami, J. Wasylyk, T. La Porte, K. Katipally, H.-J. Chung, Enzyme Microb. Technol. 28 (2001) 632-636.

65. R. Patel, A. Goswami, L. Chu, M.-J. Donovan, V. Nanduri, S. Goldberg, R. Johnston, P. J. Siva, B. Nielsen, F. Junying, W. X. He, Z. P. Shi, K. Wang, R. Eiring, D. Cazzulino, A. Singh, R. Mueller, Tetrahedron: Asymmetry, 15 (2004) 12471258.

66. A. Archelas, R. Furstoss, Top. Curr. Chem. 200 (1999) 159191.

67. A. Steinreiber, K. Faber, Curr. Opin. Biotechnol. 12 (2001) 552-558.

68. J. Catt, G. Johnson, D. Keavy, R. Mattson, M. Parker, K. Takaki, J. Yevich, US 5856529, CAN 130:110151 (1999).

69. A. Goswami, M. Totleben, A. Singh, R. Patel, Tetrahedron: Asymmetry, 10 (1999) 3167-3175.

70. B. Schnell, K. Faber, W. Kroutil, Adv. Synth. Catal. 345 (2003) 653-666.

71. H. Stecher, K. Faber, Synthesis, 1 (1997) 1-16.

72. A. Goswami, D. Mirfakhrae, R. Patel, Tetrahedron: Asymmetry, 10 (1999) 4239-4244.

73. J. Arch, Pharmacol. Rev. Commun. 9 (1997) 141-148.

74. J. Bloom, M. Dutia, B. Johnson, A. Wissner, M. Burns, E. Largis, J. Dolan, T. Claus, J. Med. Chem. 35 (1992) 3081-3084.

75. L. Fisher, P. Sher, S. Skwish, I. Michael, S. Seiler, K. Dickinson, Bioorg. Med. Chem. Lett. 6 (1994) 2253-2258.

76. R. Patel, A. Banerjee, L. Chu, D. Brzozowski, V. Nanduri, L. Szarka, J. Am. Oil Chem. Soc. 75 (1998) 1473-1482.

77. R. Patel, C. McNamee, A. Banerjee, J. Howell, R. Robison, L. Szarka, Enzyme Microb. Technol. 14 (1992) 731-738.

78. A. Matsuyama, H. Yamamoto, Y. Kobayashi, Org. Proc. Res. Develop. 6 (2002) 558-561. 
79. S. Davis, G. Christopher, H. John, D. Gray, J. Gruber, G. Huisman, S. Ma, L. Newman, R. Sheldon, WO 2004015132 A2 20040219 CAN 140:198191 AN 2004:143313, PCT Int. Appl. (2004) pp. 168.

80. A. Fishman, M. Eroshov, D.-N. Sheffer, V. Jan, U. Cogan, R. Effenberger, Biotechnol. Bioeng. 74 (2001) 256-263.

81. R. Patel, A. Banerjee, C. McNamee, D. Brzozowski, R. Hanson, L. Szarka, Enzyme Microb. Technol. 15 (1993) 10141021.

82. S. Sit, R. Parker, I. Motoe, H. Balsubramanian, C. Catt, P. Brown, W. Harte, M. Thompson, J. Wright, J. Med. Chem. 33 (1990) 2982-2999.

83. H. Gijsen, C.-H. Wong, J. Am. Chem. Soc. 116 (1994) 84228423.

84. W. Greenberg, A. Varvak, S. Hanson, K. Wong, H. Huang, P. Chen, M. Burk, Proc. Natl. Acad. Sci. USA, 101 (2004) 5788-5793.

85. M. Chaffman, R. Brogden, Drugs, 29 (1985) 387-390.

86. C. Kawai, T. Konishi, E. Matsuyama, H. Okazaki, Circulation, 63 (1981) 1035-1038.

87. T. Isshiki, B. Pegram, E. Frohlich, Cardiovasc. Drug Ther. 2 (1988) 539-544.

88. D. Floyd, R. Moquin, K. Atwal, S. Ahmed, S. Spergel, J. Gougoutas, M. Malley, J. Org. Chem. 55 (1990) 5572-5575.

89. R. Patel, R. Robison, L. Szarka, J. Kloss, J. Thottathil, R. Mueller, Enzyme Microb. Technol. 13 (1991) 906-912.

90. A. Arisawa, M. Matsufuji, T. Nakashima, K. Dobashi, K. Isshiki, T. Yoshioka, S. Yamada, H. Momose, S. Taguchi, Appl. Environ. Microbiol. 68 (2002) 2716-2725.

91. H. Waldmann, A. Heuser, S. Schulze, Tetrahedron Lett. 37 (1996) 8725-8728.

92. C. Costello, A. Kreuzman, M. Zmijewski, Tetrahedron Lett. 37 (1996) 7469-7472.

93. A. Bommarius, K. Drauz, K. Gunther, G. Knaup, M. Schwarm, Tetrahedron: Asymmetry, 8 (1997) 3197-3200.

94. J. Ogawa, S. Shimizu, Stereoselective Biocatalysis, R. Patel (Ed.), Marcel \& Dekker, New York (2000) pp. 1-22.

95. H. Sajiki, K. Hattori, K. Hirota, J. Org. Chem. 63 (1998) 7990-7992.

96. G. Royer, W. Chow, K. Hatton, J. Mol. Catal. 31 (1985) $1-13$.
97. R. Patel, V. Nanduri, D. Brzozowski, C. McNamee, A. Banerjee, Adv. Synth. Catal. 345 (2003) 830-834.

98. V. Nanduri, S. Goldberg, R. Johnston, R. Patel, Enzyme Microb. Technol. 34 (2004) 304-312.

99. G. Bisacchi, W. Slusarchyk, U. Treuner, J. Sutton, R. Zahler, S. Seiler, D. Kronenthal, M. Rondazzo, Z. Xu, Z. Shi, M. Schwinden, WO 9967215 A1 19991229 CAN 132:64103 AN 1999:819347 (1999).

100. B. Wirz, W. Walther, Tetrahedron: Asymmetry, 3 (1992) 1049-1054.

101. A. Goswami, J. Howell, E. Hua, K. Mirfakhrae, M. Soumeillant, S. Swaminathan, X. Qian, F. Quiroz, T. Vu, X. Wang, B. Zheng, D. Kronenthal, R. Patel, Org. Proc. Res. Develop. 5 (2001) 415-420.

102. O. Ward, M. Baev: In: Stereoselective Biocatalysis, R. Patel (Ed.), Marcel Dekker, New York (2000) 267-287.

103. H. Iding, P. Siegert, K. Mesch, M. Pohl, Biochim. Biophys. Acta, 1385 (1998) 307-322.

104. H. Iding, T. Dunnwald, L. Greiner, A. Liese, M. Muller, P. Siegert, J. Grotzinger, A. Demir, M. Pohl, Chem. Eur. J. 6 (2000) 1483-1495.

105. Z. Guo, Goswami, D. Mirfakhrae, R. Patel, Tetrahedron: Asymmetry, 10 (1999) 4667-4675.

106. Z. Guo, A. Goswami, V. Nanduri, R. Patel, Tetrahedron: Asymmetry, 12 (2001) 571-577.

107. E. Burcher, C. Mussap, J. Stephenson: Tachykinin Receptors, S. Buck (Ed.), Humana Press, Totowa (1994).

108. B. Veronesi, J. Carter, R. Devlin, S. Simon, M. Oortgiesen, Neuropeptides, 33 (1999) 447-456.

109. L. Yuan, E. Burcher, B. Nail, Pulm. Pharmacol. Ther. 11 (1998) 31-39.

110. P. Ting, J. Lee, J. Anthes, N.-Y. Shih, J. Piwinski, Bioorg. Med. Chem. Lett. 10 (2000) 2333-2335.

111. G. Reichard, Z. Ball, R. Aslanian, J. Anthes, J. N.-Y. Shih, J. Piwinski, Bioorg. Med. Chem. Lett. 10 (2000) 2329-2332.

112. M. J. Homann, R. Vail, B. Morgan, V. Sabesan, C. Levy, D. R. Dodds, A. Zaks, Adv. Synth. Catal. 343 (2001) 744-749.

113. W.-C. Suen, N. Zhang, L. Xiao, V. Madison, A. Zaks, Protein Eng. Des. Sel. 17 (2004) 133-140.

114. N. Zhang, W.-C. Suen, W. Windsor, L. Xiao, V. Madison, A. Zaks, Protein Eng. 16 (2003) 599-605.

\section{Biokatalitička sinteza kiralnih farmaceutskih međuprodukata}

\begin{abstract}
Sažetak
U farmaceutskoj industriji sve je važnija proizvodnja samo jednog enantiomera kao međuprodukta u proizvodnji lijekova. Kiralni međuprodukti i fine kemikalije na visokoj su cijeni u farmaceutskoj i agrokemijskoj industriji za pripravu lijekova i agrikulturnih proizvoda. Prikazan je golemi potencijal mikroorganizama za transformaciju sintetskih kemikalija što imaju kemoselektivnost, regioselektivnost i enantioselektivnost. U radu su opisani biokatalitički procesi za sintezu kiralnih farmaceutskih međuprodukata.
\end{abstract}

